\title{
Diagnostika a léčba akutního infarktu myokardu s elevacemi ST
}

\author{
Doporučení České kardiologické společnosti 2009.
}

\author{
Autorský kolektiv: Petr Widimský, Ota Hlinomaz, Petr Kala, Radovan Jirmár \\ Oponenti: Jan Vojáček, Stanislav Janoušek
}

\section{1. Úvod, definice}

Tyto doporučené postupy jsou v souladu s obdobnými doporučeními Evropské kardiologické společnosti (ESC), American College of Cardiology (ACC) a American Heart Association (AHA). Lékaři pečující v České republice o nemocné s akutním infarktem myokardu jsou povinni tyto doporučené postupy ČKS znát a v naprosté většině prrípadů se jimi řídit. Jedná se však o doporučení, nikoli o předpisy či příkazy. Lékař může použít jiný než zde doporučený postup, musí však být schopen zdůvodnit a obhájit, proč v daném př́padě takový postup použil.

Pod termínem „Akutní koronární syndromy“ se rozumějí všechny stavy spojené patofyziologicky s nestabilním plátem a na něj nasedající trombózou v koronární tepně, klinicky s klidovými bolestmi na hrudi nebo jejich ekvivalenty. Patř́i sem (podle závažnosti): Q infarkt myokardu, non-Q infarkt myokardu, nestabilní angina pectoris. Dříve patrné zřetelné rozlišení se $\mathrm{v}$ poslední době poněkud setřelo díky pokrokům v diagnostice (zejména biochemické) i v terapii (včasná reperfuze). Proto není neobvyklé, že pracovní diagnóza při prvním kontaktu s nemocným se může lišit od konečné diagnózy při propuštění nebo při úmrtí nemocného. $\mathrm{V}$ těchto „Doporučeních pro diagnostiku a léčbu infarktu myokardu“ bude pojednáno o infarktu typu Q, resp. infarktu s elevacemi ST či s blokem Tawarova raménka (tedy o stavech obvykle spojených s úplným uzávěrem koronární tepny a vyžadujících reper- fuzní léčbu). Pro stručnost, v dalším textu pojem akutní infarkt myokardu s elevacemi ST (STEMI) zahrnuje též nemocné s čerstvě vzniklým blokem Tawarova raménka. Pokud výsledkem časné reperfuze je zabránění rozvoje patologických kmitů Q (tedy de facto výsledkem je non-Q infarkt), jsou tito nemocní samozřejmě součástí těchto doporučení. Jinými slovy tato doporučení pojednávají o nemocných, kteři splňují minimálně jedno (kterékoli) ze tři EKG kritérií: elevace ST v akutní fázi, čerstvý blok Tawarova raménka, rozvoj patologických kmitů Q.

\section{Patofyziologická definice infarktu myokardu}

Infarkt myokardu (IM) je akutní ložisková ischemická nekróza srdečního svalu vzniklá na podkladě náhlého uzávěru či progresivního extrémního zúžení věnčité tepny zásobující příslušnou oblast.

\section{Př́čina koronární okluze}

Ve více než $90 \%$ je příčinou koronární ateroskleróza s rupturou intimy a trombózou v místě plátu. Asi v 5-10 \% př́padů může mít IM jiný původ (trombóza v koronární tepně bez aterosklerózy, spasmy, arteriitidy, embolie do věnčitých tepen aj.).

\section{Klinická diagnóza infarktu myokardu}

Akutní (vyvíjející se, popř. recentní) IM je definován jako typický vzestup a/nebo pokles biochemických markerů 
nekrózy myokardu (troponin T či I, CK-MB) při současné prrítomnosti alespoň jednoho $\mathrm{z}$ následujících kritérií: a) klinické prríznaky ischemie; b) vývoj patologických vln Q na EKG; c) EKG změny svědčící pro ischemii (elevace ST či deprese); d) souvislost s koronární revaskularizací (PCI, bypass); e) průkaz nové regionální poruchy kinetiky nebo nové ztráty viabilního myokardu zobrazovací metodou.

\section{Náhlá smrt způsobená infarktem myokardu}

Úmrtí, které nastalo dříve, než byl proveden odběr krve na biomarkery, nebo dříve, než mohla nastat pozitivita biomarkerů, a současně byla přítomna některá $\mathrm{z}$ těchto známek infarktu: klinické příznaky ischemie, elevace ST nebo nový raménkový blok, koronární trombus zjištěný při koronarografii nebo pitvě.

Více podrobností o definici infarktu myokardu lze nalézt $v$ dokumentu Evropské kardiologické společnosti. ${ }^{(1)}$

\section{Prognóza}

Tato doporučení pojednávají o IM s elevacemi ST, tedy o pacientech, u nichž bylo natočeno EKG. Nezabývají se prŕpady náhlých úmrtí v prehospitalizační fázi, z nichž má přibližně $25 \%$ jako příčinu náhlé smrti akutní IM (většina z těchto pacientů umírá arytmickou smrtí bez prokazatelné souvislosti s čerstvým IM). Mluvíme-li tedy o prognóze pacientů s diagnózou STEMI, pak mluvíme o nemocniční mortalitě a dlouhodobé mortalitě po propuštění.

Prognóza STEMI je zcela zásadně ovlivněna následujícími třemi faktory:

1. stavem oběhu v okamžiku diagnózy - tzv. Killipova klasifikace,

2. způsobem a včasností léčby,

3. věkem pacienta.

Rozdíly v nemocniční mortalitě způsobené těmito faktory jsou i při moderní léčbě (primární PCI) dramatické: od $70 \%$ mortality nemocných $>75$ let věku ve trrídě Killip IV až po $1 \%$ mortalitu nemocných $<75$ let věku ve třídě Killip I. Další významné faktory, které ovlivňují mortalitu, jsou: lokalizace infarktu, rozsah koronárního postižení (nemoc kmene či tři tepen znamená horší prognózu), přidružená onemocnění (renální insuficience, diabetes mellitus aj.), př́itomnost nižšího krevního tlaku a vyšší srdeční frekvence a další méně podstatné faktory. ${ }^{(2,3)}$

Zavedení trombolytické léčby infarktu myokardu na přelomu osmdesátých a devadesátých let 20. století snížilo hospitalizační mortalitu takto léčených pacientů přibližně na 7-18 \% (registry), resp. na 6-10\% (randomizované studie). Zavedení primární PCI na počátku 21. století snížilo hospitalizační mortalitu STEMI na 5-10 \% (registry), resp. na 3-7\% (randomizované studie). V kombinaci s optimální doprovodnou farmakologickou léčbou a důslednou sekundární prevencí je tedy možné očekávat jednoměsíční mortalitu u konsekutivních (neselektovaných) pacientů léčených primární PCI zhruba 6-9\%. Výrazně nižší údaj o mortalitě ( $<5 \%)$ téměř vždy znamená určitou preselekci (např. velmi starých osob, terminálních kardiogenních šoků apod.).

Primární PCI je spojena také se snížením výskytu mechanických komplikací infarktu (ruptur) a kardiogenního šoku; ${ }^{(4)}$ přesto zůstává mortalita těchto stavů relativně velmi vysoká - nejméně $50 \%$ v případě kardiogenního šoku. Dlouhodobou prognózu pacientů ovlivňuje jejich primární léčba, ale také některé faktory, jako je vyšší věk, přítomnost srdečního selhání a další. Celková roční mortalita nemocných se STEMI (tj. včetně úmrtí v akutní fázi), léčených PCI, činí asi $12-17 \%$ a do deseti let umírá přibližně $50 \%$ nemocných. ${ }^{(5)}$

\section{Jak se má chovat pacient a jeho okolí při náhlé bolesti na prsou}

Typickým a nejčastějším příznakem IM je svíravá, pálivá nebo tlaková bolest na prední ploše hrudníku. V některých prípadech se bolest může objevit atypicky mezi lopatkami, v zádech, v nadbřišku, v krku, v dolní čelisti nebo v horních končetinách, a do těchto oblastí se může také šírit $\mathrm{z}$ hrudníku. Podezření na probíhající infarkt vyvolává kontinuální bolest trvající déle než 10 minut. Mohou ji předcházet kratší ataky bolestí. Druhým nejčastějším prríznakem je dušnost a relativně často jsou přítomny další doprovodné príznaky, jako jsou nausea či zvracení, palpitace, pocení, slabost, mdloby nebo úzkost. Až v $50 \%$ vzniku IM předcházejí projevy nestabilní anginy pectoris. ${ }^{(6)}$ Kombinace bolesti a uvedených dalších príznaků je vždy varující a vyžaduje rychlý odborný zásah. Přibližně v 10-20\% případi̊ mohou být příznaky mírné, žádné nebo atypické, se kterými se často setkáváme ve vyšším věku a u diabetiků. ${ }^{(7)}$ $\mathrm{V}$ těchto př́padech je vždy nutné pomýšlet na možnost diagnózy IM.

V akutní fázi onemocnění je čas zásadním faktorem ovlivňujícím mortalitu. Proto je nutné při vzniku výše uvedených symptomů vždy co nejdríve kontaktovat zdravotnickou záchrannou službu na telelefonu 155 (popř. 112). Operátor, kterým je školený zdravotník, je na tomto telefonním čísle bez předvolby a zdarma dostupný 24 hodin denně ze všech typů telefonů. Během 15 minut by měl $\mathrm{k}$ pacientovi dorazit vůz rychlé lékařské pomoci, vybavený 12svodovým EKG pro správné stanovení diagnózy STEMI a přístroji pro zajištění základní resuscitační péče, včetně zevní kardiostimulace. Co nejdříve po stanovení diagnózy je pacient převezen do nejbližšího PCI centra s nepřetržitým provozem ( 24 hodin denně 7 dní v týdnu) pro primární PCI.

\section{Přednemocniční diagnostika a léčba. Organizace péče o nemocné s podezřením na akutní infarkt myokardu}

\section{1. Časové intervaly v přednemocniční etapě} $\mathrm{V}$ prehospitalizační fázi by měly být registrovány následující časové intervaly: ${ }^{(8,9)}$ 
a) Doba „bolest - telefon“. Čas od začátku obtíží do okamžiku, kdy nemocný zavolá lékařskou pomoc (nebo se sám dostaví $\mathrm{k}$ lékaři do ordinace). Tato doba by měla $\mathrm{v}$ ideálním prrípadě činit 10 minut. V reálné praxi bohužel trvá průměrně 2-3 hodiny. Je ovlivnitelná osvětou.

b) Doba „telefon - první kontakt se zdravotnickým personálem“. V optimálním případě by měl být lékař u nemocného s podezřením na infarkt do 15 minut od zavolání, $\mathrm{v}$ řídce osídlených oblastech může být tato doba delší. Zdravotnická záchranná služba (ZZS) by k pacientovi $s$ prríznaky možného infarktu měla vždy vyslat vůz s lékařem a s vybavením 12 svodovým EKG a resuscitačními pomůckami, včetně defibrilátoru a zevní kardiostimulace.

c) Vyšetření a léčba nemocného na místě. Vyšetření (včetně EKG) a základní léčebná opatření v prehospitalizační fázi by neměla trvat déle než 15 minut.

d) Doprava do nemocnice. Trvání optimálně 15-20 minut, v rrídce osídlených oblastech déle. Delší (max. 90 minut) může být $\mathrm{v}$ případech, kdy je nemocný transportován na primární PCI. Pokud EKG křivka natočená ZZS na místě zásahu ukáže elevace ST nebo blok Tawarova raménka, musí lékař záchranné služby telefonicky informovat př́slušné katetrizační centrum o přijetí nemocného, vhodného k primární PCI. Pacient s elevacemi ST na EKG nemá být transportován do nejbližší nemocnice, ale vždy přímo do nejbližšího kardiologického (PCI) centra. Přijímající kardiologické pracoviště pak v době, kdy je nemocný transportován, připraví katetrizační sál pro primární PCI a lůžko koronární jednotky. Tímto jednoduchým zpo̊sobem lze zkrátit na minimum čas do reperfuze (pacient přijíždí přímo na již připravený katetrizační sál).

Celkem tedy v prehospitalizační fázi by reakce zdravotnické služby (doba „telefon - katetrizační sál“, tj. b + c + d) měla $\mathrm{v}$ optimálním př́padě trvat $<60$ minut, vždy však méně než 120 minut. Cílem organizace přednemocniční péče na všech úrovních tedy musí být takový systém, aby každý nemocný s podezřením na srdeční infarkt byl nejpozději do 120 minut na katetrizačním sále (samozřejmě čím dříve, tím lépe).

\subsection{Organizace přednemocniční etapy}

Při podezření na akutní IM se má vždy volat ZZS. Vozy záchranné služby by měly být vždy vybaveny přenosným 12svodovým EKG, defibrilátorem (optimálně jeho kombinací s transkutánním kardiostimulátorem), přenosným ventilátorem a dalšími pomůckami pro resuscitaci. Volání terénní lékařské služby (lékařské pohotovosti či praktického nebo odborného lékaře) je zbytečnou ztrátou času pro nedostatečnou vybavenost i nedostatečnou zkušenost $s$ akutními infarkty na této úrovni! Dostupnost záchranné služby by měla být organizována tak, aby v $95 \%$ případů byl čas „telefon - prŕíjezd“ kratší než 15 minut. Nejvíce nemocných umírá v prehospitalizační fázi infarktu na maligní arytmie fibrilaci komor. ${ }^{(10)}$ Protože čas do defibrilace určuje prognó- zu těchto nemocných, stále více se ve světě prosazuje použití tzv. automatických externích defibrilátorů pro nezdravotnické záchranné složky, tedy hasiče, policisty a dále pro bezpečnostní pracovníky, letecký personál apod.

\subsection{Diagnostické postupy $v$ přednemocniční fázi} Vyslovení podezření na IM, popř. stanovení této diagnózy již v prehospitalizační fázi, musí být učiněno rychle. Lékař prvního kontaktu (obvykle lékař záchranné služby) má $\mathrm{k}$ dispozici jen dvě možnosti: anamnézu a přenosný 12svodový EKG. Nemocného s podezřením na akutní IM je nutno převézt ihned na kardiologické oddělení nemocnice bez ohledu na znalost biochemických a koagulačních vyšetření. Normální nebo netypické EKG v prvních hodinách nevylučuje zcela akutní IM! Fyzikální vyšetření včetně pečlivého vyšetření pulsu a krevního tlaku může odhalit některé komplikace infarktu. EKG (12svodový) musí být samozrejmou součástí výbavy všech vozů ZZS vyjiždějících $k$ nemocným s bolestmi na hrudi.

\subsection{Výběr nemocnice, do níž je pacient záchrannou službou převážen}

Podle doporučení Evropské kardiologické společnosti a Evropské rady pro resuscitaci ${ }^{(10)}$ nemusí být nemocný $s$ akutním infarktem prevezen do nejbližší nemocnice. Je prokázáno, že transport k primární PCI je bezpečný minimálně pro transporty do $90 \mathrm{~min},{ }^{(9)}$ což odpovídá času od prvního kontaktu lékaře s pacientem (first medical contact) do první dilatace („balloon“) < 120 min, resp. času od telefonátu pacienta o pomoc do první dilatace $<135$ min. Rozhodnutí, kam nemocného s podezřením na akutní IM transportovat, musí být učiněno na základě:

a) 12svodové EKG křivky (optimálně natočené na místě prvního kontaktu, popř. v nejbližší nemocnici ihned po příjezdu - v takovém případě tentýž vůz záchranné služby, který nemocného přivezl, nemocného ihned odváží do kardiologického centra; zdržení v nejbližší nemocnici tak nesmí přesáhnout $15 \mathrm{~min}$ ),

b) odhadu trvání transportu a dostupnosti primární PCI. Při průkazu elevací ST na EKG či raménkové blokády (STEMI) a dostupnosti primární PCI ukazuje optimální rozhodovací strategii tabulka 1 .

Indikace $\mathrm{k}$ transportu nemocného záchrannou službou přímo do intervenčního kardiologického centra k primární PCI ukazuje tabulka 2.

Zde navržený systém převozu by měl vést $\mathrm{k}$ tomu, že naprostá většina nemocných s akutním infarktem myokardu a elevacemi ST bude vozem ZZS (vybaveným 12svodovým EKG) transportována $\mathrm{z}$ místa zásahu prrímo do nejbližšího intervenčního kardiologického centra.

Pokud je STEMI diagnostikován z jakýchkoli důvodů jinak, než je výše uvedeno (tj. jinak než posádkou ZZS na místě prvního kontaktu s nemocným), platí pro tyto nemocné od okamžiku natočení diagnostického EKG stejná pravidla - tj. mají být neprodleně ZZS převezeni na katetrizační sál. Pokud je diagnóza STEMI stanovena v nemocnici 
Tabulka 1 Časové rozhodovací schéma pro transport pacientů se STEM

\begin{tabular}{|c|c|c|}
\hline & $\begin{array}{l}\text { Čas „EKG - katlab“ } \\
<90 \text { min (odpovídá } \\
\text { času EKG - první } \\
\text { dilatace < } 120 \text { min) }\end{array}$ & $\begin{array}{l}\text { Čas „EKG - katlab“ } \\
>90 \text { min (odpovídá } \\
\text { času EKG - první } \\
\text { dilatace > } 120 \text { min) }\end{array}$ \\
\hline $\begin{array}{l}\text { Čas „bolest - EKG" } \\
<2 \mathrm{~h}\end{array}$ & $\mathrm{p}-\mathrm{PCl}$ & $\mathrm{TL}$ \\
\hline $\begin{array}{l}\text { Čas „bolest - EKG“ } \\
2-12 \mathrm{~h}\end{array}$ & $\mathrm{p}-\mathrm{PCl}$ & $\mathrm{p}-\mathrm{PCl}$ \\
\hline $\begin{array}{l}\text { Čas „bolest - EKG" } \\
12-24 \mathrm{~h}\end{array}$ & $\begin{array}{l}\text { p-PCI při přetrvání } \\
\text { elevací ST nebo } \\
\text { symptomů }\end{array}$ & $\begin{array}{l}\text { p-PCI při přetrvání } \\
\text { elevací ST nebo } \\
\text { symptomů }\end{array}$ \\
\hline
\end{tabular}

Čas „bolest - EKG“ je reálná celková doba od začátku př́znaků infarktu do natočení 12svodového EKG. Čas „EKG - katlab“ je předpokládaná doba od natočení diagnostického EKG (tj. príprava transportu + transport + přesun z vozu na katetrizační sál).

Katlab - katetrizační laboratoř, p- $\mathrm{PCl}$ - primární perkutánní koronární intervence, $\mathrm{TL}$ - trombolýza

bez možnosti PCI, musí být zajištěn odjezd nemocného do PCI centra nejpozději do 30 minut od stanovení diagnózy. Není nutné se zdržovat podrobnou překladovou zprávou, stačí křivka EKG s elevacemi ST, velmi stručný záznam o vyšetření, seznam diagnóz a seznam podaných léků.

\subsection{Léčebná opatření v přednemocniční fázi}

\subsubsection{Analgezie a sedace}

Podání opiátů. Fentanyl $(50 \mu \mathrm{g} / \mathrm{ml}) 2 \mathrm{ml}$ i.v., popř. přidávat po $1 \mathrm{ml}$ do utlumení bolesti, do celkové dávky $200 \mu \mathrm{g} / \mathrm{h}$, alternativou je podání morphini chloridum 2-4 mg i.v. s opakováním dávky do maximální celkové dávky $10 \mathrm{mg}$ i.v. Volba dávky se řídí hodnotou krevního tlaku a intenzitou bolesti. Nežádoucím účinkem může být zvracení (léčba: thiethylperazini hydrogenomalas, Torecan, $6,5 \mathrm{mg}=1 \mathrm{ml}$ i.v.) nebo (zejména při rychlém i.v. podání) hypotenze a bradykardie (léčba: atropin 0,5-1,0 mg i.v.).

Terapie nesteroidními antiflogistiky kromě kyseliny acetylsalicylové (ASA), a to jak neselektivními inhibitory, tak inhibitory COX-2, je považována za nevhodnou pro zvý-

Tabulka 2 Indikace k okamžitému transportu pacienta se STEMI zdravotnickou záchrannou službou do intervenčního kardiologického centra

1. Absolutní indikace

- Akutní (< 12 hodin) IM s elevacemi ST či s čerstvým blokem Tawarova raménka a s kontraindikací trombolýzy (bez ohledu na vzdálenost do $\mathrm{PCl}$ centra);

- Akutní (<48 hodin) IM provázený známkami srdečního selhán nebo hypotenzí či šokem;

- Akutní (< 12 hodin) IM s elevacemi ST či s čerstvým blokem Tawarova raménka bez kontraindikace trombolýzy, pokud je reálné předání pacienta na katetrizační sál do 90 minut od natočení diagnostického EKG.

2. Relativní indikace

- Ostatní IM (elevace či deprese ST či raménkový blok) s přetrvávajícími stenokardiemi s časem dojezdu do intervenčního centra > 90 min (12-24 h od vzniku obtíží) šené riziko úmrtí, reinfarktu, srdečního selhání. ${ }^{(9)}$ Každý nemocný s IM má obavy ze smrti, proto rozhovor vysvětlující podstatu choroby a možnosti léčby, obvykle spolu s opiáty, stačí k uklidnění. $\mathrm{V}$ opačném př́padě je na místě podání sedativ.

\subsubsection{Antitrombotická léčba v prehospitalizační fázi}

Kyselina acetylsalicylová 200-400 mg per os (nutno rozžvýkat v ústech pro dosažení časnějšího účinku) patří mezi základní opatření ihned při podezření na infarkt nebo nestabilní anginu pectoris. Je možno použít také i.v. preparát kyseliny acetylsalicylové (Aspégic, Kardégic) v dávce $0,25-0,5 \mathrm{~g}$.

Clopidogrel. Podání clopidogrelu 300 mg je indikováno vždy v akutní fázi STEMI, vyšší dávku (600 mg) lze použít $\mathrm{u}$ pacientů indikovaných $\mathrm{k}$ primární $\mathrm{PCI}$ (třída IIa B). ${ }^{(3)}$

Heparin $\mathrm{v}$ prehospitalizační fázi je indikován před transportem na primární PCI (třída IA). V tomto případě by měl být podán současně s ASA a clopidogrelem. Podává se formou intravenózního bolusu $100 \mathrm{j} . / \mathrm{kg}$ hmotnosti pacienta. Pokud se předpokládá podání abciximabu či eptifibatidu během PCI, je nutné, aby dávka heparinu podaná v prehospitalizační fázi činila pouze $60 \mathrm{j} . / \mathrm{kg}$. Heparin před uvažovanou trombolýzou alteplázou či reteplázou: i.v. bolus 60 j./kg, max. 4000 j. i.v.

\subsubsection{Léčba levostranné srdeční insuficience $\checkmark$ prehospitalizační fázi}

Kyslík. Podání kyslíku (kyslíková maska, CPAP [continuous positive airway pressure] maska) po dobu trvání bolesti nebo pokud jsou přítomny známky srdečního selhání nebo šoku. Dále vždy při poklesu saturace $\mathrm{O}_{2}<90 \%$; doporučuje se též podání $\mathrm{O}_{2}$ všem pacientům $s$ nekomplikovaným STEMI. U nemocných ve třídě Killip II (chrůpky na plicích či cval) podáváme kyslík maskou nebo intranasálně; u nemocných ve třídě Killip III (plicní edém) neinvazivní ventilaci maskou s CPAP (většinou s PEEP [positive end expiratory pressure]) či intubaci s klasickou umělou plicní ventilací (UPV); ve třídě Killip IV (kardiogenní šok) je zpravidla nejvhodnější intubace a UPV bez zbytečného odkladu.

Diuretika. Při městnavém srdečním selhání je indikováno nitrožilní podání furosemidu v dávce 40-80 mg (tř́ida IC).

Nitráty. Infuze s nitráty je indikována při srdečním selhání, při hypertenzi provázející IM a při persistujících či recidivujících stenokardiích (trǐ́da IC). Rutinní podávání všem nemocným se STEMI není indikováno (tř́ída IIb).

Opiáty viz výše.

\subsubsection{Léčba hypertenze, podání beta-blokátorů $\checkmark$ prehospitalizační fázi}

Beta-blokátory. Podání beta-blokátorů p.o. je plně indikováno v prvních 24 hodinách akutního IM při respektování absolutních a relativních kontraindikací (třída IA) a je účelné především u nemocných s hypertenzí či tachykardií bez známek srdečního selhání či zvýšeného rizika kardiogenního šoku. Rutinní podávání beta-blokátoru všem ne- 
mocným v prehospitalizační fázi je však sporné a za vhodnější je považován individuální postup. Rutinní, profylaktické podávání i.v. beta-blokátorů $\mathrm{v}$ akutní fázi je řazeno do trrídy IIb B. Takové podání beta-blokátorů sice přispívá $\mathrm{k}$ potlačení bolesti, tachyarytmií a omezuje negativní vliv stresu na rozvíjející se nekrózu, ale může zvýšit relativní riziko rozvoje kardiogenního šoku až o 30 \% (studie COMMIT/CCS-2). ${ }^{(11)}$

Nitráty viz výše.

\subsubsection{Léčba hypotenze a šoku v prehospitalizační fázi}

Volumexpanze (úvodní infuze 250-500 ml krystaloidu či plasmaexpanderu $\mathrm{s}$ přihlédnutím $\mathrm{k}$ přítomnosti a tíži plicního městnání).

Katecholaminy. Při rozvoji kardiogenního šoku (pokud není způsoben závažnou arytmií či současnou hypovolemií) je na místě i.v. infuze s dobutaminem $5-10 \mu \mathrm{g} / \mathrm{kg} / \mathrm{min}$ (tř́ída IIa B) a/nebo dopaminem (třída IIb C). Pokud nestačí toto opatření k udržení krevního tlaku, je možno podat noradrenalin i.v. v dávce $0,1-0,5 \mu \mathrm{g} / \mathrm{kg} / \mathrm{min}$.

\subsubsection{Léčba srdeční zástavy, bradykardie, elektromechanické disociace}

Kardiopulmocerebrální resuscitace (KPCR). Defibrilátor, přenosný ventilátor, prostředky $\mathrm{k}$ intubaci aj. musejí být $\mathrm{k}$ dispozici po celou dobu transportu do nemocnice. Detailní doporučení pro KPCR viz Doporučení European Resuscitation Council pro KPR. ${ }^{(10)}$

Adrenalin v dávce $1 \mathrm{mg}$ i.v. či 2-3 mg endotracheálně je základním lékem při resuscitaci pro asystolii či elektromechanickou disociaci. Dávku adrenalinu opakujeme v intervalech 3-5 minut během KPR.

Atropin při asystolii či bradykardii < 45/min („cave“ možný paradoxní účinek u bradykardie se širokými QRS). Atropin 0,5-1,0 mg i.v., popř. opakovaně do maximální dávky 2,0-2,5 mg. Při asystolii začínáme dávkou 2 mg i.v., max. dávka je 3,0 mg.

Transkutánní kardiostimulace. Tento zpo̊sob kardiostimulace je pro nemocného bolestivý a vyžaduje analgosedaci a někdy i napojení na umělou plicní ventilaci. Tuto metodu volíme po co nejkratší nutnou dobu, tj. během transportu do zařízení, které je schopno provést transvenózní stimulací, a to v indikaci extrémní bradykardie nereagující na atropin; zejména, je-li provázena hypotenzí. Vždy je nutné ozřejmení, zda je dostatečná i mechanická srdeční akce.

Řizená hypotermie ${ }^{(12)}$ - její zahájení po resuscitaci již během transportu je vhodné, pokud její realizace nevede $\mathrm{k}$ prodloužení doby transportu k primární PCI. V přednemocniční fázi se provádí ledovými obklady a infuzí studených krystaloidů.

\subsubsection{Léčba fibrilace komor a širokokomplexové tachykardie (VT)}

Defibrilace se provádí výboji energií 150-360 J bifázického proudu nebo $360 \mathrm{~J}$ monofázického proudu, další výboj po dvou minutách KPCR je stejné intenzity.

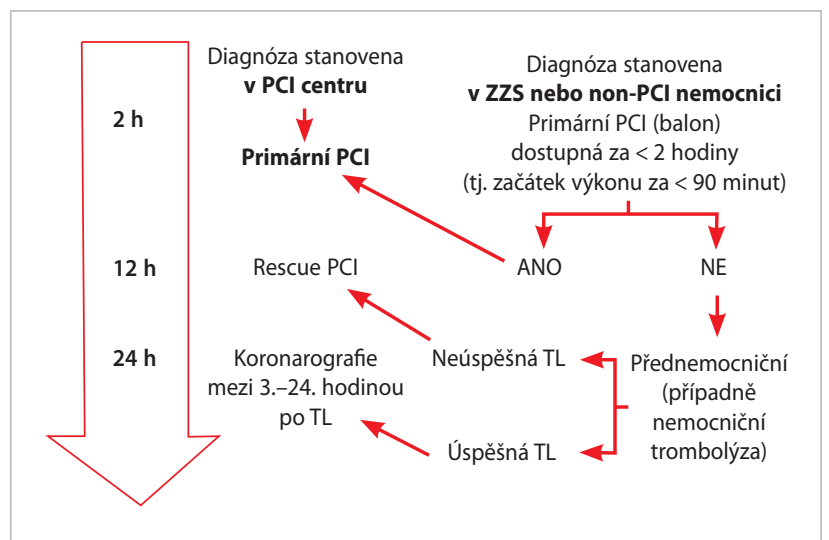

Obrázek 1 Rozhodovací schéma pro volbu reperfuzní strategie

Adrenalin v dávce $1 \mathrm{mg}$ i.v. se podává po dvou zhruba dvouminutových cyklech KPCR + dvou neúspěšných defibrilacích u resistentní fibrilace komor či VT před třetím výbojem.

Antiarytmika. Amiodaron 150-300 mg i.v. během 10 min při hemodynamicky stabilní VT či jako bolus při refrakterní fibrilaci komor či VT („cave“ arytmie při prodlouženém intervalu QTc!!). Alternativou je podání i.v. trimekainu. Při recidivujících nesetrvalých VT je indikováno podání beta-blokátorů i.v. (třída IIa). Preventivní podávání antiarytmik všem nemocným v prehospitalizační fázi není indikováno.

\section{Reperfuzní, revaskularizační}

\section{a antitrombotická léčba v akutní fázi}

Při rozhodování o reperfuzní léčbě platí následující principy:

> každý nemocný se STEMI by měl být indikován k reperfuzní léčbě (primární perkutánní koronární intervencí [p-PCI] nebo trombolýze, viz tabulka 3, obrázek 1),

\section{Tabulka 3 Klíčové indikace $\mathbf{z}$ doporučených postupů ESC}

Indikace k primární PCl:

- STEMI $<12$ h od začátku př́znaků (IA)

- STEMI 12-48 h od začátku příznaků, pokud jsou přítomny klinické a/nebo EKG známky pokračující ischemie (Ila C)

- Čas "diagnostické EKG - první dilatace“ musí být vždy < 120 min (IB)

- Čas „první EKG - balon“ musí být < 90 min u pacientů s EKG natočeným v prvních dvou hodinách od začátku příznaků, kteří mají velký IM a nízké riziko krvácení (IB)

- STEMI s rozvojem srdečního selhání či šoku (IB)

- STEMI s kontraindikací k trombolýze (IB)

- STEMI 12-24 h od začátku příznaků, príiznaky již odezněly (Ilb B)

$\mathrm{PCl}$ uzavřené infarktové tepny u pacientů bez pokračující ischemie za více než 24 h není indikována (IIIB).

Další intervenční postupy:

- Rescue PCl do 12 h od začátku obtíži (Ila A)

- Aspirace trombu u všech nemocných (Illb B)

- Facilitovaná PCI (IIIA)

Prevence a/nebo léčba „no-reflow“ fenoménu:

- Aspirace trombu selektivně podle angiografie (Ila B)

- Abciximab po dobu 12-24 h (Ila B)

- Adenosin (llb B)

- Verapamil (IIb C) 
> neindikování reperfuzní léčby u nemocného, který má v době prvního kontaktu s lékařem klinické a EKG př́znaky STEMI, je nutno kvalifikovat jako hrubou chybu,

> p-PCI má vždy přednost před trombolýzou kromě níže uvedených situací s hrozící velkou ( $>2$ h) časovou prodlevou.

Čas $<2$ hodiny znamená čas od prvního kontaktu lékaře s pacientem (tj. zpravidla čas od natočení prvního EKG) do provedení PCI. V předchozích kapitolách byl uváděn čas telefon - PCI < 135 minut; tento čas zahrnoval ještě 15 minut na dojezd vozu ZZS.

\subsection{Primární perkutánní koronární intervence}

Perkutánní koronární intervence je jednoznačně nejúčinnější léčbou akutního IM (jak STEMI, tak i non-STEMI). Nemá prakticky žádné kontraindikace a je mnohem účinnější než trombolýza. Trombolýza dokáže včas zrekanalizovat uzavřenou věnčitou tepnu pouze asi u $50 \%$ léčených pacientů, zatímco PCI je úspěšná přibližně v 90-95\% případů. Navíc se prokázalo, že v zemích, kde byla úspěšně zavedena p-PCI do široké praxe (Česká republika, Švédsko, Dánsko, Nizozemsko), se zvýšil počet nemocných léčených jakoukoli reperfuzní léčbou. Primární PCI v randomizovaných studiích, ve srovnání s trombolýzou, snížila mortalitu nemocných se STEMI zhruba o 20-25\% (mortalita 3-7 \% při p-PCI vs. 6-10 \% při trombolýze), ${ }^{(13-15)} \mathrm{v}$ registrech je rozdíl mezi oběma metodami ještě výraznější (mortalita 5-10 \% při p-PCI vs. 7-18 \% při trombolýze). Výskyt kombinovaného ukazatele (smrt/reinfarkt/iktus) je při léčbě p-PCI dokonce o $45 \%$ nižší než při léčbě trombolýzou.

Ze všech nemocných, odeslaných k urgentní koronarografii (a p-PCI) pro susp. STEMI, je p-PCI reálně provedena přibližně u $90 \%$. Ze zbylých $10 \%$ přibližně $2 \%$ nemocných mají normální koronarografii (viz dále), asi $3 \%$ mají v době urgentní koronarografie již obnovený (spontánní rekanalizací či podáním antitrombotické medikace) normální koronární průtok (TIMI-3), pro nález nemoci tří tepen či kmene podstoupí koronární bypass (většinou v odloženém termínu, viz dále); asi $5 \%$ nemocných má koronární anatomii nevhodnou pro PCI (takže p-PCI se u nich bud'vůbec nezkoušela, nebo byla technicky neúspěšná).

Primární PCI se provádí většinou jako predilatace balonkovým katetrem, následuje implantace stentu. Pokud je po zavedení intrakoronárního vodiče přítomen koronární průtok TIMI-2 či TIMI-3, lze provést primoimplantaci stentu bez předchozí predilatace balonkovým katetrem. Zatím jsou nejednotné názory na rutinní použití lékových stentů v této indikaci a rovněž na rutinní použití tromboaspiračního katetru. $\mathrm{V}$ individuálních případech jsou tyto postupy někdy cenné (snížení rizika restenózy lékovým stentem u nemocných s vyšším rizikem restenózy, odsátí angiograficky viditelného většího intrakoronárního trombu sníží riziko „no-flow“ fenoménu). ${ }^{(16)}$

Vzhledem $\mathrm{k}$ tomu, že koronarografie se dnes stala po EKG zpravidla druhým vyšetřením, provedeným u vět- šiny pacientů s akutním STEMI, používají se široce dva způsoby hodnocení funkčního výsledku PCI: hodnocení koronárního průtoku pomocí klasifikace TIMI (Thrombolysis In Myocardial Infarction - viz tabulka 4) a hodnocení myokardiální perfuze pomocí klasifikace MBG (Myocardial Blush Grade - viz tabulka 5).

\subsection{Trombolytická léčba}

Trombolytická léčba se v České republice (ČR) k léčbě IM již téměř přestala používat. Léčí se jí pouze asi $1 \%$ pacientů se STEMI - zpravidla v mimořádných situacích, kdy p-PCI není dostupná (sněhová kalamita, technická porucha katetrizačního sálu apod.). Proto se v této kapitole omezíme pouze na nejdůležitější informace o indikacích a kontraindikacích (viz tabulka 6).

\subsection{Kombinace trombolýzy a koronarografie/PCI (facilitovaná $\mathrm{PCl}$, rescue $\mathrm{PCl}$, PCI následující den)}

Facilitovaná PCI je definována jako plánovaná kombinovaná strategie trombolýzy s rychle navazující PCI. Teoreticky lze od této strategie očekávat nejvyšší účinnost v dosažení reperfuze: trombolýza je podána okamžitě po stanovení diagnózy a PCI je provedena v čase, který je srovnatelný s časem do samotné primární PCI (bez trombolýzy). Nicméně tato strategie opakovaně selhala ve čtyřech různých randomizovaných studiích, ${ }^{(17-20)}$ které prokázaly vyšší mortalitu a zejména významně více reinfarktů po facilitované PCI ve srovnání s prostou primární PCI (bez trombolýzy). Samozřejmě byl větší počet i krvácivých komplikací. Facilitovaná PCI tedy není indikována podle současných doporučení ESC v žádné situaci.

Rescue PCI je definována jako PCI po neúspěšné trombolýze. Z definice vyplývá, že je třeba vyčkat výsledku trombolýzy a teprve poté (při přetrvávání elevací ST a/nebo stenokardií za hodinu po zahájení trombolýzy) rozhodnout o př́padné rescue PCI. Indikace k rescue PCI je tedy opožděna nejméně o hodinu ve srovnání s indikací facilitované PCI. Převážet pacienta k rescue PCI má tedy smysl jen v situaci, kdy lze očekávat záchranu ještě výrazného množství myokardu - tedy zejména po neúspěšné trombolýze, která byla prováděna $\mathrm{v}$ prvních třech hodinách od začátku obtíží.

Koronarografie ( \pm PCI) za 3-24 hodin po trombolýze. Nová doporučení ESC ${ }^{(9)}$ doporučují provést koronarografii u všech úspěšně trombolyzovaných nemocných, ne ihned po trombolýze, ale za 3-24 hodin (viz tabulka 7). V praxi to tedy znamená, že všichni nemocní se STEMI by měli být

Tabulka 4 Hodnocení koronárního průtoku

TIMI-0 Žádný průtok (tepna se neplní za uzávěrem)

TIMI-1 Prosak přes uzávěr (kontrast se opožděně dostane za uzávěr, kde stagnuje a nedoteče do periferie tepny)

TIMI-2 Zpomalený průtok (kontrast se dostane až do periferie tepny, ale s jasně patrným zpožděním)

TIMI-3 Normální průtok (stejně rychlý jako průtok neinfarktovou tepnou) 
Tabulka 5 Hodnocení opacifikace myokardu kontrastem

MBG-0 Žádná opacifikace myokardu kontrastem

MBG-1 Minimální opacifikace

MBG-2 Snížená opacifikace (menší než v povodí neinfarktové tepny)

MBG-3 Normální opacifikace (stejná jako v povodí neinfarktové tepny)

MBG - Myocardial Blush Grade

přijímáni do PCI center (nejlépe přímo k primární $\mathrm{PCI}$; pokud to není možné, tak sekundárně $\mathrm{k}$ rescue $\mathrm{PCI}$ či $\mathrm{k}$ časné koronarografii).

\subsection{Koronární bypass (CABG) v akutní fázi infarktu myokardu}

Koronární bypass není vhodnou standardní léčebnou metodou pro akutní IM. Jen výjimečně je indikován emergentně v akutní fázi rozvíjejícího se infarktu. Častěji je indikován elektivně po odeznění akutní fáze infarktu.

Při indikaci emergentního koronárního bypassu pro rozvíjející se STEMI musí pacient splňovat všechna tři následující kritéria:

1. čas od začátku obtíží do zahájení operace méně než 4 h,

2. koronarografický nález nelze vyřešit pomocí PCI,

3. ischemická oblast myokardu je natolik rozsáhlá, že výsledný infarkt je pro nemocného rizikovější než akutní operace.

Elektivní koronární bypass je indikován zpravidla pro kritickou nemoc tří tepen nebo kmene levé věnčité tepny zjištěnou při koronarografii. Pokud měl nemocný při primární PCI implantován koronární stent, a je po odeznění akutní fáze infarktu dále asymptomatický, je vhodné odložit provedení srdeční operace o 4-6 týdnů; u nejrizikovějších nemocných alespoň o dva týdny. Pacientovi by se měl vysadit clopidogrel nejméně pět dnů před termínem operace. Další informace viz kapitola 8.

\subsection{Pacienti se suspektní STEMI a normální koronarografií}

Přibližně u $2 \%$ pacientů odeslaných k urgentní koronarografii se suspektní STEMI je koronarografický nález překvapivě normální. Ve většině těchto př́padů jde o jinou kardiologickou diagnózu (akutní myokarditida, akutní perikarditida, stresem indukované omráčení myokardu, kardiomyopatie, plicní embolie, disekce aorty aj.). Jen asi v $0,5 \%$ případů jde o skutečný akutní infarkt myokardu s normální koronarografí. V těchto prrípadech je koronarografie provedena $\mathrm{v}$ době, kdy nemocný již nemá elevace ST či stenokardie, a lze předpokládat, že v čase obtíží byla prítomna obstrukce koronární tepny spasmem či přechodným trombem, které po iniciální léčbě odezněly.

\subsection{Antitrombotická léčba při primární $\mathrm{PCl}$}

Základem antitrombotické léčby před p-PCI a během p-PCI je trojkombinace: kyselina acetylsalicylová $(A S A)+$ clopido-
Tabulka 6 Indikace a kontraindikace trombolýzy podle ESC ${ }^{(9)}$

Indikace trombolýzy:

- STEMI $<2$ h od začátku př́znaků při nedostupnosti p-PCl do 90 min od natočení diagnostického EKG a při absenci kontraindikací trombolýzy (IA)

- Fibrin-specifické trombolytikum (IB)

- Trombolýza (pokud je indikována) by měla být podána v přednemocniční etapě (Ila B)

Kontraindikace trombolýzy (v ČR při dostupnosti p-PCI jsou fakticky všechny kontraindikace trombolýzy absolutní a prakticky znamenají automatickou indikaci k p-PCI):

- Hemoragický nebo nejasný iktus kdykoli v minulosti

- Ischemický iktus v posledních šesti měsících

- Trauma, nádor či operace centrálního nervového systému

- Krvácení do gastrointestinálního traktu (GIT) v posledním měsíci

- Známá krvácivá porucha

- Disekce aorty

- Nekompresibilní vpichy (jaterní biopsie, lumbální punkce apod.)

- Transitorní ischemická ataka v posledních šesti měsících

- Léčba perorálními antikoagulancii

- Těhotenství či první týden po porodu

- Refrakterní hypertenze $>180 \mathrm{~mm} \mathrm{Hg}$ (systolická) a/nebo $110 \mathrm{~mm} \mathrm{Hg}$ (diastolická)

- Pokročilá jaterní choroba

- Infekční endokarditida

- Aktivní vředová choroba

- Protrahovaná resuscitace

- Trauma či operace v posledních 2-4 týdnech

grel + heparin (viz tabulka 8). Všechny tři léky by měly být podány ihned po stanovení diagnózy suspektní STEMI (tedy ihned po natočení první EKG křivky - v prehospitalizační fázi záchrannou službou, popř. na př́ijmové ambulanci prvního zdravotnického zařízení). Pokud jsou podány ve správných dávkách (ASA 200-500 mg i.v. nebo rozžvýkat v ústech, clopidogrel 300-600 mg p.o., heparin bolus 100 j./kg i.v.), není již nutné přidávat další dávky během PCI. Během PCI je vhodné podání abciximabu (případně integrilinu), což však vyžaduje redukci dávky heparinu přibližně o třetinu (tj. na dávku 60-70 j./kg). Proto tam, kde je abciximab rutinně podáván, je nutné, aby se centrum PCI dohodlo se zdravotnickou záchrannou službou na podávání menších iniciálních dávek heparinu. Vhodné je provádět test ACT (aktivovaný koagulační čas) či test APTT (aktivovaný parciální tromboplastinový čas) během p-PCI s cílem titrovat podle výsledku dávky heparinu. Pokud se však respektuje dávkování podle tělesné hmotnosti a pokud se bere v úvahu časový faktor (doba podání heparinu ve vztahu k zahájení a k trvání PCI), lze se obejít i bez těchto vyšetření v průběhu PCI. Vhodná jsou i po PCI k určení bezpečného času vytažení zavaděče $\mathrm{z}$ femorální tepny (APTT by mělo být $<50 \mathrm{~s}$ ). $\mathrm{V}$ př́ípadě radiálního přístupu je situace jednodušší - zavaděč lze vytahnout bezprostředně po výkonu.

V některých oblastech $\mathrm{v}$ zahraničí se místo kombinace heparin + abciximab podává bivalirudin, nebot̉ se ukázalo, že je po něm méně krvácivých komplikací než po zmíněné dvojkombinaci. Studie s bivalirudinem měly však některé metodické nedostatky: nebyly dvojitě slepé, bivalirudin nebyl srovnáván se samotným heparinem (bez abciximabu), ale pouze s dvojkombinací heparin + abciximab. 
Tabulka 7 Koronarografie u pacientů léčených trombolýzou a u pacientů bez reperfuzní léčby (podle doporučení ESC) ${ }^{(9)}$

Okamžitě:

- Neúspěšná TL či pochyby o jejím výsledku

- Rekurentní ischemie, reinfarkt

- Hemodynamická či elektrická nestabilita za 3-24 h

- U všech nemocných po úspěšné TL

Před propuštěním:

- U stabilních pacientů bez reperfuzní léčby

\subsection{Další antitrombotická léčba při trombolýze}

Kyselina acetylsalicylová se před trombolýzou podává zcela stejným způsobem jako před primární PCI. Clopidogrel se před trombolýzou podává ve vysycovací dávce $300 \mathrm{mg}$ pouze nemocným $<75$ let věku; starším nemocným se podává první dávka clopidogrelu pouze $75 \mathrm{mg}$. Z antikoagulancií se při trombolýze doporučuje podání enoxaparinu, heparinu nebo fondaparinuxu. Dávky a délka podávání viz citace 9 .

\subsection{Antitrombotická léčba u nemocných, kteří nebyli léčeni reperfuzní terapií}

Tito nemocní by měli dostávat ASA, clopidogrel a fondaparinux (viz tabulka 9).

\subsection{Perkutánní koronární intervence více tepen v akutní fázi}

Provádění PCI jiné než infarktové tepny v akutní fázi infarktu ( $t j$. v rámci jednoho výkonu společně s primární PCI infarktové tepny) je kontraindikováno. Důvod je prostý: klinicky a angiograficky stabilní koronární stenóza (byt by se jednalo o 90\% proximální stenózu) zpravidla neohrožuje pacienta na životě, zatímco př́padná komplikace této PCI by znamenala akutní ischemii ve druhém povodí současně, a tudíž př́mé ohrožení života pacienta.

Výjimkou může být pouze situace, kdy z koronarografie a EKG není jasné, která ze dvou kriticky zúžených či uzavřených tepen je tepnou infarktovou, nebo zcela vzácná situace, kdy je koronarograficky patrný trombus ve dvou tepnách (dvě nestabilní léze). Doporučení ESC připouští provedení PCI na více tepnách v akutní fázi STEMI u nemocných v kardiogenním šoku, kteří mají kritické stenózy

Tabulka 8 Farmakoterapie před primární $\mathrm{PCl} /$ při primární $\mathrm{PCl}$ podle doporučení ESC

- ASA $200-500$ mg či $250-500$ mg i.v. (IB)

- Clopidogrel 300-600 mg (IC)

- Heparin bolus 100 j./ kg i.v., dále ACT 250-350 s, ukončit po PCI (IC). Redukce dávky, pokud nemocný dostává současně inhibitory GPIIb/IIla.

- Abciximab bolus $0,25 \mathrm{mg} / \mathrm{kg}$ i.v., dále 0,125 $\mathrm{\mu g} / \mathrm{kg} / \mathrm{min}$, max. dávka $10 \mu \mathrm{g} / \mathrm{min}$ po dobu maximálně 12 hodin (Ila $\mathrm{A}$ )

- Bivalirudin bolus $0,75 \mathrm{mg} / \mathrm{kg}$ i.v., dále infuze $1,75 \mathrm{mg} / \mathrm{kg} / \mathrm{h}$ do skončení PCl; ACT není potřeba (lla B)

- Tirofiban (Illb B)

- Eptifibatid (Ilb C)

- Fondaparinux (IIIB) i na dalších tepnách. V těchto př́padech je vhodný individuální postup, reflektující konkrétní klinický průběh šoku (včetně vývoje hemodynamiky během PCI) a koronarografický nález (PCI na dalších tepnách má smysl u skutečně kritických lézí omezujících průtok, rozhodně není na místě u jasně stabilních „nekritických“ stenóz). Př́lilš dlouhá procedura (multivessel PCI) s použitím většího množství kontrastní látky může znamenat zhoršení hemodynamiky pacienta v kardiogenním šoku. Rychlá (s použitím minima kontrastu) úspěšná PCI pouze na infarktové tepně je ve většině př́ípadů šoku optimálním postupem.

PCI dalších tepen mimo akutní fázi infarktu je probrána $v$ kapitole 8.

\section{Ostatní léčebné postupy během hospitalizace}

\subsection{Beta-blokátory}

Beta-blokátory snižují tepovou frekvenci, systémový krevní tlak a kontraktilitu, což vede ke zlepšení koronárního průtoku (prodloužením diastoly) a současně ke snížení nároků myokardu na přísun kyslíku (snížením srdeční práce). Na druhé straně může jejich negativně inotropní účinek zhoršovat hemodynamický stav pacienta. O dlouhodobém perorálním podávání beta-blokátorů nemocným po infarktu myokardu není pochyb, nebot snižují mortalitu a výskyt reinfarktu o 20-25\%.(ㄹ) Otázkou zůstává, kdy a v jaké formě léčbu beta-blokátory zahájit. Všechny významné studie $s$ beta-blokátory byly navíc provedeny u pacientů po trombolýze. Informace o léčbě pomocí direktní $\mathrm{PCI}$ a následném podávání beta-blokátorů jsou proto skoupé. Beta-blokátory indikujeme při přijetí u nemocných s AIM, kteří mají rychlejší srdeční akci (> 80/min) současně s hypertenzí a dobrou funkcí levé srdeční komory. Naopak jsou zcela nevhodné, jestliže je přítomno srdeční selhání, známky nízkého srdečního výdeje, interval $\mathrm{PQ}>0,24 \mathrm{~s}, \mathrm{AV}$ blokáda druhého nebo třetího stupně nebo asthma bronchiale. ${ }^{(11)}$ Cílem musí být dosažení tepové frekvence 50-70/min a systolického krevního tlaku kolem 120 mm Hg. $\mathrm{U}$ většiny nemocných zahajujeme léčbu beta-blokátory perorálně, a to již v průběhu prvních 24 hodin. $V$ případě zvýšeného rizika vzniku kardiogenního šoku (systolický krevní tlak $<120 \mathrm{~mm} \mathrm{Hg}$, sinusová tachykardie nad 100/min) se jim raději v prvních hodinách vyhneme. Začínáme nižší dávkou a postupně ji zvyšujeme do maximálních tolerovaných hodnot. U pacientů s poruchou funkce levé komory s léčbou začínáme později a jsme $\mathrm{v}$ titraci dávky opatrnější. Pokud se rozhodneme pro intravenózní podání beta-blokátorů (indikace pro rutinní podávání je IIb podle doporučení ESC), aplikujeme nejprve testovací dávku (např. 2,5-5 mg metoprololu i.v.), kterou lze po pěti minutách opakovat až do celkové dávky $15 \mathrm{mg}$ i.v. (viz tabulka 10).

\subsection{Statiny}

Dlouhodobá léčba statiny (inhibitory HMG-CoA-reduktázy) je indikována u všech nemocných s akutním koronárním 
Tabulka 9 Jakou antitrombotickou léčbu podat pacientovi, který nebyl léčen $v$ akutní fázi reperfuzí

- ASA 200-400 mg (IA)

- Clopidogrel 75 mg (IB)

- Fondaparinux bolus $2,5 \mathrm{mg}$ i.v., dále $2,5 \mathrm{mg}$ s.c. jednou denně po dobu 8 dnů nebo do propuštění (IB)

- Při nedostupnosti fondaparinuxu podat heparin či enoxaparin (IB)

syndromem s cílem dosáhnout koncentrace LDL-cholesterolu $<2,5 \mathrm{mmol} / \mathrm{l}$, u pacientů $\mathrm{s}$ největším rizikem 1,5-2,0 mmol/1. ${ }^{(22)}$ Nejvyšší riziko mají pacienti s akutním IM, kteří mají současně diabetes mellitus a difuzní mnohočetné postižení věnčitých tepen. Statiny snižují koncentraci lipidů v krvi, ale mají i řadu nelipidových účinků, které ve svém důsledku vedou ke stabilizaci aterosklerotického plátu. Podáváme je nejméně ve středně vysoké dávce (fluvastatin $80 \mathrm{mg}$, simvastatin $40 \mathrm{mg}$, atorvastatin $20 \mathrm{mg}$, rosuvastatin $10 \mathrm{mg}$ ) již od prvního dne hospitalizace. Výjimkou jsou pacienti s hypoperfuzním poškozením jater, kdy léčbu zahajujeme až po zlepšení jaterních funkcí. U jiných hepatopatií opakovaně kontrolujeme transaminázy. S léčbou statinů začínáme bez ohledu na vstupní hodnoty lipidů. Všem nemocným s akutním IM by měl být odebrán lipidový profil nalačno během prvních 24 hodin od vzniku obtíží.

\subsection{Inhibitory angiotensin konvertujícího enzymu, blokátory receptorů $\mathrm{AT}_{1}$ pro angiotensin II a inhibitory aldosteronu}

Inhibitory angiotensin konvertujícího enzymu (ACE) aplikujeme hemodynamicky stabilizovaným nemocným s akutním infarktem myokardu již v prvních 24 hodinách a podáváme je dlouhodobě. $Z$ léčby mají největší prospěch pacienti se srdečním selháním nebo s dysfunkcí levé komory $(\mathrm{EF} \leq 40 \%)$ a normálním nebo zvýšeným krevním tlakem, dále pacienti s hypertenzí, diabetem nebo chronickou ledvinovou nedostatečností. ${ }^{(23,24)} \mathrm{U}$ hemodynamicky nestabilních nemocných počkáme $s$ jejich podáváním do dosažení oběhové stabilizace. $\mathrm{V}$ př́ípadě kontraindikací nebo intolerance inhibitorů ACE jsou lékem volby antagonisté angiotensinu II (AIIA).

Inhibitory aldosteronu (spironolacton, eplerenon) dlouhodobě podáváme nemocným po STEMI, kteří jsou již léčeni plnou dávkou inhibitorů ACE a beta-blokátorů, mají $\mathrm{EF} \leq 40 \%$ a současně srdeční selhání nebo diabetes mellitus. Podmínkou jejich aplikace jsou normální renální funkce a nepřítomnost hyperkalemie. Nemocným musíme pravidelně kontrolovat koncentraci kalia v krvi. Léčbu zahajujeme za hospitalizace.

\subsection{Antiarytmika}

Profylaktické podávání antiarytmik s výjimkou beta-blokátorů u hemodynamicky nezávažných arytmií při akutním IM není indikováno. Důležité jsou opakované kontroly kalia v krvi s cílem normalizace jeho hodnot. U závažných tachyarytmií (komorové tachykardie, fibrilace a flutter síní) je
Tabulka 10 Rutinní léčba STEMI v nemocniční fázi; ASA + clopidogrel + heparin v bolusových dávkách pouze $v$ př́padě, že nebyly tyto léky podány $v$ prehospitalizační fázi

\begin{tabular}{|c|c|}
\hline Kyselina acetylsalicylová & 250-500 mg i.v., poté 100 mg p.o. \\
\hline Clopidogrel & $\begin{array}{l}\text { 300-600 mg p.o., poté } 75 \text { mg } \\
\text { jednou denně }\end{array}$ \\
\hline $\begin{array}{l}\text { Heparin, } \\
\text { popř. fondaparinux } \\
\text { či enoxaparin) }\end{array}$ & $\begin{array}{l}\text { heparin } 100 \text { j./kg bolus i.v. před } \\
\text { p-PCI nebo } 60 \text { j./kg i.v. před PCI } \\
\text { s abciximabem nebo před trombolýzou } \\
\text { (kromě streptokinázy) }\end{array}$ \\
\hline Statiny & $\begin{array}{l}\text { vysoká dávka s dosaženým cílem } \\
\text { LDL-cholesterolu }<2,5 ; \text { u vysoce } \\
\text { rizikových pacientů s LDL-cholesterolem } \\
1,5-2,0 \mathrm{mmol} / /\end{array}$ \\
\hline Beta-blokátory & $\begin{array}{l}\text { 1. den, vytitrovat maximálně } \\
\text { tolerovanou dávku }\end{array}$ \\
\hline Inhibitory ACE & $\begin{array}{l}\text { 1. den, vytitrovat maximálně } \\
\text { tolerovanou dávku }\end{array}$ \\
\hline Inhibitory aldosteronu & $\begin{array}{l}\text { EF }<40 \% \text { a srdeční selhání } \\
\text { nebo diabetes mellitus }\end{array}$ \\
\hline
\end{tabular}

nejvýhodnější amiodaron. Amiodaron je indikován u nemocných se setrvalou nebo hemodynamicky kompromitující komorovou tachykardií, u pacientů s opakovanými symptomatickými běhy nesetrvalé monomorfní komorové tachykardie a u polymorfní komorové tachykardie za předpokladu, že interval QT není prodloužen. Podáváme jej v bolusové dávce 150 mg během 10 minut, kterou lze několikrát opakovat. Udržovací infuzi amiodaronu v 5\% glukóze podáváme rychlostí $1 \mathrm{mg} / \mathrm{min}$ prvních šest hodin a poté $0,5 \mathrm{mg} / \mathrm{min}$. Celková dávka amiodaronu v prvních 24 hodinách by neměla překročit $1,2 \mathrm{~g}$. Pacientům s normální systolickou funkcí levé komory bez známek srdečního selhání lze ve stejných indikacích podat sotalol i.v. $0,5-1,5 \mathrm{mg} / \mathrm{kg}$ jako bolus během 10 minut. Dávku lze po šesti hodinách opakovat do maximální dávky 640 mg za 24 hodin. U rezistentních závažných arytmií zkusíme podat magnesium 10-20 mg pomalu i.v. Nemocné s fibrilací síní s rychlou odpovědí komor léćíme beta-blokátory a amiodaronem. Alternativou $\mathrm{v}$ případě normální systolické funkce levé komory je verapamil $5 \mathrm{mg}$ i.v. U tachyfibrilace síní se srdečním selháním lze podat digoxin i.v. $(0,25-0,5 \mathrm{mg}$, popř. opakovat za dvě hodiny do maximální dávky $1,5 \mathrm{mg}$ ). Cílem je zpomalit frekvenci komor, a tím snížit spotřebu kyslíku myokardem. Atropin v dávce $0,5 \mathrm{mg}$ bolus i.v., kterou lze opakovat do celkové dávky $3 \mathrm{mg}$, je vhodný u pacientů se sinusovou bradykardií s hypotenzí a při AV blokádě II. stupně a III. stupně.

\subsection{Blokátory kalciových kanálů}

Nemají místo v rutinní léčbě akutního IM. Výjimkou je verapamil, který lze podat nemocným s nekardiální kontraindikací beta-blokátorů. Verapamil nelze použít u snížené systolické funkce levé komory nebo u srdečního selhání. Verapamil se nemá podávat současně s beta-blokátory - u vnímavých jedinců hrozí těžká deprese funkce myokardu. 


\begin{tabular}{|c|c|c|}
\hline & Definice & $\begin{array}{l}\text { 30denní a roční } \\
\text { mortalita* }\end{array}$ \\
\hline Třída I & $\begin{array}{l}\text { Chrůpky na plicích } \\
\text { ani 3. ozva nejsou prítomny }\end{array}$ & $2,8 \%$ a $6,9 \%$ \\
\hline Třída II & $\begin{array}{l}\text { Chrůpky }<50 \% \text { plic } \\
\text { a/nebo } 3 . \text { ozva }\end{array}$ & $10,9 \%$ a $20,1 \%$ \\
\hline Trída III & $\begin{array}{l}\text { Chrůpky } \geq 50 \% \text { plic - } \\
\text { známky plicního edému }\end{array}$ & $20,6 \%$ a $41,3 \%$ \\
\hline Trída IV & Kardiogenní šok & $38,0 \%$ a $62,4 \%$ \\
\hline
\end{tabular}

\subsection{Nitráty}

Intravenózní nitráty jsou indikovány u všech nemocných se srdečním selháním, hypertenzí a persistujícími stenokardiemi v prvních 48 hodinách. Nitráty jsou kontraindikovány, jestliže pacient vzal v posledních 24 hodinách inhibitor fosfodiesterázy 5 (PDE-5). Pro rutinní profylaktickou aplikaci i.v. a perorálních nitrátů nemáme dostatek přesvědčivých důkazů.

\subsection{Léčba diabetes mellitus}

Př́tomnost diabetes mellitus a vysoká glykemie při přijetí u pacientů s akutním IM negativně ovlivňují jejich prognózu. Diabetici s akutním IM mají dvakrát vyšší mortalitu a častěji se u nich manifestuje srdeční selhání než u nediabetiků. ${ }^{(25)}$ Nedávno publikovaná studie DIGAMI-2 neprokázala rozdíl v mortalitě mezi diabetiky léčenými okamžitou infuzí inzulinu, s následnou dlouhodobou inzulinovou léčbou, nebo pacienty léčenými okamžitou inzulinovou infuzí s následnou běžnou léčbou nebo s dosud běžnou léčbou diabetu. ${ }^{(26)}$ Naopak, řada studií s kriticky nemocnými diabetiky prokázala prrínos razantní inzulinové léčby. ${ }^{(27)}$ Pozor musíme dávat na nebezpečí hypoglykemie, jejíž vznik negativně ovlivňuje osud pacienta. Při léčbě diabetika s AIM doporučujeme udržovat glykemii v rozmezí 5,0-7,8 mmol/1. Hodnotám $<5,0 \mathrm{mmol} / \mathrm{l}$ bychom měli zabránit opakovaným stanovením glykemie a úpravou dávky inzulinu. Po dosažení uspokojivé kompenzace glykemie pomocí inzulinu nejčastěji aplikujeme metformin, který je ale nevhodný u pacientů se srdečním nebo renálním selháním.

\subsection{Léčba renální dysfunkce}

Pacienti s poškozenou funkcí ledvin a akutním IM mají horší prognózu než nemocní bez ní. ${ }^{(28)} \mathrm{K}$ posouzení renální dysfunkce stanovujeme glomerulární filtraci, koncentraci kreatininu nebo cystatinu C. Ke zhoršení funkce ledvin u nemocných s AIM může dojít v důsledku hypoperfuze ledvin při hemodynamické nestabilitě, při podání kontrastní látky při primární $\mathrm{PCI}$, při léčbě inhibitory ACE, AIIA a diuretiky. Základním opatřením v prevenci a léčbě renální dysfunkce je dostatečná hydratace pacienta.

\section{Vyšetřovací postupy během hospitalizace}

\subsection{Monitorování EKG}

Každý pacient s podezřením na probíhající STEMI by měl být minimálně po dobu $24 \mathrm{~h}$ od přijetí do nemocnice uložen na lůžko s průběžným monitorováním EKG. Důvodem je především riziko život ohrožujících bradyarytmií nebo tachyarytmií, které vyžadují okamžitý léčebný zásah. Jde o arytmie hemodynamicky netolerované - tzn. fibrilaci komor (FK), flutter nebo setrvalou komorovou tachykardii s výskytem asi ve $20 \%,{ }^{(20)}$ a kompletní atrioventrikulární blok (AVB III. st.), který je běžný u STEMI dolní stěny, především ve spojení s postižením pravé srdeční komory (výskyt asi v $7 \%$ ). ${ }^{(30)}$ Mezi akutně méně závažné arytmie nebo převodní poruchy patří fibrilace síní s výskytem v 10-20\% a AVB I.-II. stupně a blokády Tawarových ramének. Stavy spojené s akutním vznikem převodní poruchy jsou provázeny vyšším rizikem hospitalizační a následné mortality, ${ }^{(31)}$ které odpovídá většímu rozsahu myokardiální ischemie a nekrózy. $\mathrm{V}$ případě výskytu závažných arytmií je do jejich potlačení nutná hospitalizace na intenzivním monitorovaném lůžku, následně je vhodné tyto pacienty monitorovat pomocí telemetrie. Délka monitorování je př́sně individuální, pohybuje se od 24 hodin u nekomplikovaných nemocných po úspěšné p-PCI do více než týdne u nejrizikovějších nemocných s těžkou dysfunkcí levé komory a recidivujícími arytmiemi.

\subsection{Echokardiografie}

Zvolení optimální individuální péče se neobejde bez znalosti funkce srdce jako pumpy a znalosti morfologie a fyziologie srdečních stuktur. V této oblasti hraje nezastupitelnou roli echokardiografie jako neinvazivní metoda, a za optimálních podmínek také vyšetřovací metoda „bed-side“, která by měla být využita pokud možno již $v$ průběhu prvních 24 hodin od prijetí pacienta a zcela jistě pred jeho propuštěním. Vedle prvotní informace, týkající se rozsahu akutně probíhající ischemie, je možné získat některé závažné informace o dalších stavech (např. jizva po starém infarktu myokardu či současně přítomná chlopenní vada). Významným způsobem může pomoci také u pacientů $\mathrm{v}$ klinicky těžkém stavu pro detekci mechanických komplikací infarktu, posouzení vlivu chlopenních abnormalit či patologií, sledování účinku léčby a další. Echokardiografie má klíčový diferenciálně-diagnostický význam (odlišení od plicní embolie, akutní perimyokarditidy, disekce aorty apod.). Získané vstupní informace tvoří zároveň základ pro následné posouzení remodelace levé komory a rizikovosti pacienta.

\subsection{Koronarografie}

Indikace koronarografie nebo rekoronarografie jsou probrány samostatně, připomenutí však zasluhují stavy vyžadující jejich urgentní provedení. Poinfarktová angina pectoris, rekurence myokardiální ischemie nebo infarktu myokardu jsou $\mathrm{z}$ tohoto pohledu považovány za indikace absolutní. Vždy je však nutné posouzení individuální 
s ohledem na předchozí klinické, elektrokardiografické, echokardiografické a laboratorní projevy.

\subsection{Zátěžová vyšetření}

$\mathrm{V}$ éře mechanické reperfuzní léčby, poskytující akutně znalost koronárního řečiště, se zátěžová vyšetření indikují za hospitalizace zcela výjimečně a spíše se někdy využívají v následné ambulantní fázi onemocnění. Tam poskytují dobrou informaci o celkovém kardiovaskulárním stavu pacientů a jejich funkční výkonnosti.

\subsection{Diagnóza omráčeného a hibernovaného myokardu, viability}

Na rozdíl od nekrotické části myokardu postiženého ireverzibilně rozsáhlou ischemií je možné na srdci nalézt také oblasti s poruchou funkce pouze přechodnou. Pro klinickou praxi je zásadním odlišení myokardu tzv. omráčeného (stunning) od hibernovaného. Na rozdíl od omráčeného myokardu, u kterého mohou probíhat reparační změny po odstranění prríčiny ischemie myokardu ještě po dobu přibližně dvou týdnů, je hibernace myokardu ovlivnitelná pouze revaskularizací. ${ }^{(32)}$ Rozhodnutí o indikaci př́padné revaskularizace je zásadní a může být život ovlivňující, především u pacientů s těžkou systolickou dysfunkcí LK.

$\mathrm{V}$ praxi se pro stanovení viabilního myokardu a jeho odlišení od oblasti nekrózy nebo jizvy nejčastěji využívají následující metody: perfuzní scintigrafie (SPECT - single photon emission tomography) a dobutaminová „zátěžovác echokardiografie. Přesnější metody, jako jsou pozitronová emisní tomografie (PET) a magnetická rezonance, se využívají zatím omezeně. ${ }^{(33,34)}$

\subsection{Odhad rizika náhlé smrti}

Důležitou součástí rizikové stratifikace pacientů je určení rizika náhlé smrti. Je známo, že výskyt maligních komorových arytmií (komorová tachykardie nebo fibrilace komor) v průběhu prvních 48 hodin od vzniku obtíží je spojen $s$ vyšší hospitalizační mortalitou bez vlivu na další prognózu. Naopak, s vysokým rizikem je spojen jejich pozdější výskyt především ve spojení se systolickou dysfunkcí levé srdeční komory. ${ }^{(35)} \mathrm{V}$ těchto př́ípadech je nutné zvážit případné provedení maximální možné revaskularizace viabilních oblastí myokardu intervenční nebo chirurgickou cestou. Předpoklad zlepšení prognózy je založen na odstranění myokardiální ischemie jako spouštěcího mechanismu arytmií, přestože vědecké důkazy pro tento př́istup chybějí. Nedílnou součástí léčby je i maximální snaha o vytvoření a udržení optimálního stavu oběhové kompenzace a vnitřního prostředí. Bez dalších diagnostických nebo léčebných kroků se lze obejít u pacientů $s$ relativně dobrou ejekční frakcí levé komory (EF LK) $\geq 40 \%$, u kterých se nevyskytla symptomatická komorová arytmie. Naopak to platí v př́padě pacientů s vysokým rizikem náhlé smrti, tzn. se systolickou dysfunkcí levé srdeční komory, s EF < 40 \% a výskytem fibrilace komor (FK) nebo hemodynamicky významné setrvalé komorové tachykardie (SKT $\geq 30$ s) po uplynutí prvních
48 hodin od vzniku obtíží. V prevenci náhlé srdeční smrti se u pacientů takto vysoce ohrožených náhlou arytmickou smrtí jeví jako nejúčinnější implantace kardioverteru-defibrilátoru (ICD). Tento př́stup je spojen s $23-55 \%$ snížením mortality ve srovnání s konzervativně léčenou skupinou pacientů; tato léčba by měla být metodou první volby. ${ }^{(9,36)}$ Zatím s nedostatečnou prediktivní hodnotou náhlé smrti jsou spojeny další testy založené na podrobném rozboru EKG. V př́padě komorových tachykardií (KT) s podezřením na re-entry mechanismus je doporučeno provedení elektrofyziologického vyšetření s př́padnou ablační léčbou. Definitivní indikace ICD by však měla být stanovena s odstupem nejméně 40 dnů od IM a tento interval je prodloužen na tři měsíce $\mathrm{v}$ případě, že pacient prodělal revaskularizaci.

V doporučeních ČKS se této problematiky týkají dvě indikační skupiny:

1. pacienti s dokumentovanou epizodou nesetrvalé KT při ischemické chorobě srdeční (po IM, s dysfunkcí LK, tj. s EF $\leq 35 \%$, s indukcí setrvalé KT nebo FK při programované stimulaci komor za standardní farmakologické léčby včetně beta-blokátorů);

2. pacienti s ischemickou chorobou srdeční, kteří mají těžkou poinfarktovou dysfunkci (EF $\leq 30 \%)$, rozšíření komplexu QRS (> 120 ms) a známky chronického srdečního selhání NYHA II, minimálně šest měsíců po IM za standardní farmakologické léčby včetně beta-blokátorů. ${ }^{(37,38)}$

\section{Revaskularizační léčba mimo akutní fázi infarktu}

V současné době naprostá většina pacientů se STEMI podstoupí koronarografii během prvních 24 hodin - bud' před primární PCI, nebo po trombolýze (viz kapitola 5). Znalost koronarografie tedy umožňuje rozdělit nemocné po recentním STEMI do několika skupin:

1. Vyřešený pacient (pacienti s úspěšně ošetřenou infarktovou tepnou pomocí primární PCI, bez významných stenóz na dalších tepnách nebo se stenózami pouze na menších větvích).

2. Pacient s částečnou revaskularizací (p-PCI infarktové tepny, zbývají významné stenózy na dalších tepnách).

3. Pacient $s$ neúspěšnou reperfuzní léčbou (neúspěšná p-PCI či trombolýza, přetrvává uzávěr infarktové tepny).

4. Pacient s reperfuzí po iniciální medikamentózní léčbě a s nálezem vhodným k elektivní revaskularizaci.

Diagnostická koronarografie, rekoronarografie, prípadně revaskularizace pomocí PCI nebo bypassové operace jsou za hospitalizace indikovány vždy u poinfarktové anginy pectoris, při reinfarktu, srdečním selhání v průběhu prvních 48 hodin u pacientů bez známého koronárního nálezu, při průkazu zátěžové ischemie myokardu nebo při vzniku maligních komorových arytmií po více než 48 hodinách od vzniku obtíží s ischemií myokardu, jako možnou vyvo- 
lávající příčinou. Ve většině akutních situací je zvažována možnost revaskularizace pomocí PCI, popř. konzervativní léčba. Operační řešení je metodou volby u vzniku mechanické komplikace infarktu myokardu nebo preferenčně u pacientů s velmi významným koronárním postižením (kombinace postižení kmene levé věnčité tepny a všech hlavních tepen provázených dysfunkcí levé srdeční komory). Sporadicky je možné indikovat bypassovou operaci také po neúspěšné primární PCI nebo u koronárního postižení, technicky nevhodného $\mathrm{k}$ intervenční léčbě. Je-li pacient stabilizován a nemá-li pokračující ani recidivující ischemii, je vhodné termín operace odložit na dobu asi za dva týdny po IM. Naopak, u pacientů oběhově nestabilních či s recidivující nebo pokračující ischemií je nutné určit termín operace individuálně (zpravidla platí $\mathrm{v}$ těchto případech „čím dříve, tím lépe“).

Rekanalizace infarktové tepny u pacientů s již doběhlou ischemií (více než 24-48 hodin od vzniku obtíží) a bez průkazu zátěžové ischemie nepřináší klinický prospěch a v současnosti ji nelze rutinně doporučit. ${ }^{(39)}$

\section{Diagnostika a léčba komplikací infarktu myokardu}

\subsection{Srdeční selhání v průběhu akutního infarktu myokardu}

Akutní levostranné srdeční selhání při akutním IM výrazně zhoršuje prognózu nemocného. ${ }^{(40)}$ Jeho prŕíčinou je nejčastěji rozsáhlé poškození myokardu, dále i srdeční arytmie, ischemická mitrální regurgitace a ruptura mezikomorového septa. Projevuje se dušností, chrůpky na plicích, sinusovou tachykardií a cvalem (3. ozvou) na srdci při auskultaci. Mezi základní vyšetření patří RTG snímek srdce a plic a echokardiografie. Při těžších formách invazivně monitorujeme systémový krevní a centrální žilní tlak, někdy měříme tlaky v pravostranných srdečních oddílech, $\mathrm{v}$ plicnici a srdeční index pomocí plovoucího Swanova-Ganzova katetru. Srdeční selhání při akutním infarktu myokardu rozdělujeme podle Killipovy klasifikace do čtyř stupňů (Killip I-IV), viz tabulka 11. Nemocní se srdečním selháním patří mezi nejvíce ohrožené a musejí být léčeni v kardiocentrech pomocí primární PCI.

\section{Lehčí až středně závažné srdeční selhání - Killip II}

Základem léčby je kyslík, který podáváme nosními brýlemi nebo maskou. Vždy monitorujeme saturaci krve kyslíkem s cílem dosáhnout hodnoty saturace $\geq 95 \%$. Indikujeme diuretika i.v., nejčastěji furosemid $20-40 \mathrm{mg}$. V prŕṕpadě renálního selhání a chronické léčby kličkovými diuretiky používáme dávku vyšší. Dávku lze opakovat v závislosti na rozsahu městnání na plicích a na diuréze. Vhodné je kontinuální, intravenózní podávání furosemidu. Dále aplikujeme i.v. nitráty, jestliže není přítomna hypotenze. Prognózu nemocného zlepšují inhibitory ACE, které podáváme vždy, nejsou-li kontraindikace. Léčbu malou dávkou inhibitory ACE můžeme zahájit již první den akutního IM a postupně ji zvyšujeme. Obecně platí, že čím je stupeň srdečního selhání vyšší, tím větší význam má primární PCI ve srovnání s trombolýzou.

\section{Těžké srdeční selhání (plicní edém) - Killip III}

Základem léčby je opět kyslík a furosemid i.v. Morfin $\mathrm{v}$ dávce 2,5-5 mg i.v. zlepšuje dušnost. Dávku lze podle potřeby opakovat. Vasodilatační léčbu nitráty i.v. indikujeme tehdy, jestliže není hypotenze; jejich dávku titrujeme podle krevního tlaku. Při hypertenzi můžeme začít bolusem i.v., po kterém pokračujeme $\mathrm{v}$ infuzi. Nejčastěji používáme glycerol-trinitrát i.v. nebo isosorbid dinitrát i.v. Cílem je snížení systolického krevního tlaku o 15-30 mm Hg nebo na $100 \mathrm{~mm} \mathrm{Hg}$. Dále sledujeme saturaci krve kyslíkem pomocí pulsního oxymetru a krevní plyny metodou podle Astrupa. Většina nemocných s plicním edémem by měla mít neinvazivní plicní ventilaci s pozitivním tlakem na konci exspirace (PEEP). Endotracheální intubaci s umělou plicní ventilací indikujeme $\mathrm{v}$ případě hyposaturace krve kyslíkem přes výše uvedenou léčbu. Nemocní mají výrazný prospěch z rychlého otevření infarktové tepny pomocí přímé $P C I$.

Kardiogenní šok - Killip IV

Kardiogenní šok je kritické snížení prokrvení periferních tkání a orgánů vzniklé v důsledku závažné poruchy srdeční funkce (nejčastěji levé komory srdeční). Definujeme ho jako pokles systolického krevního tlaku $<90 \mathrm{~mm} \mathrm{Hg}$, doprovázený tachykardií a prŕznaky oběhové nedostatečnosti (periferní vasokonstrikce, bledost či cyanóza, studený pot, pokles diurézy $<20 \mathrm{ml} / \mathrm{h}$, zmatenost). Nejčastější př́ičinou kardiogenního šoku je akutní infarkt myokardu postihující alespoň 30-40\% levé komory. Ve velké většině případů najdeme difuzní těžké postižení věnčitých tepen (nemoc tří tepen či kmene) a rozsáhlou poruchu kinetiky. Při uzávěru jedné věnčité tepny a normálním nálezu na zbylých věnčitých tepnách vzniká kardiogenní šok jen výjimečně. Rozvoj šoku musíme proto předpokládat u nemocných s IM v jiné lokalizaci, než byl předchozí IM, nebo s uzávěrem druhé věnčité tepny při známém chronickém uzávěru jiné tepny. Nezbytností je vyloučení jiných příčin hypotenze. Mezi ně patří hypovolemie, infarkt pravé komory, nežádoucí účinek léků (např. trombolytika, nitráty, opiáty), vagová reakce, arytmie nebo elektrolytové poruchy. Okamžitě provedeme echokardiografické vyšetření k určení funkce levé i pravé srdeční komory a k vyloučení mechanických komplikací akutního IM měříme centrální žilní tlak. Dále můžeme zavést plovoucí katetr do plicnice a určovat tlak v plicnici v zaklínění a srdeční index. Intraarteriálně monitorujeme krevní tlak, měříme krevní plyny, saturaci smíšené žilní krve kyslíkem, laktát a diurézu. Metodou volby v léčbě počínajícího kardiogenního šoku u akutního IM je přímá $P C I$, kterou musíme provést co nejdř́ve. ${ }^{(42)}$ Při nutnosti dlouhého transportu na PCI u nemocných se šokem v prvních třech hodinách od vzniku infarktu zvažujeme okamžité podání trombolytika, a $\mathrm{v}$ každém případě nemocného převezeme co nejrychleji k urgentní koronarografii. Z léků podáváme pozitivně inotropní léky. Při těžké hypotenzi aplikujeme noradrenalin 0,5-30 $\mu \mathrm{g} / \mathrm{min}$ i.v. s cílem dosáh- 
nout systolického krevního tlaku alespoň 80 mm Hg. Jakmile se systémový krevní tlak zvýší na > 90 mm Hg, můžeme přidat dobutamin $\mathrm{v}$ dávce $2-20 \mu \mathrm{g} / \mathrm{kg} / \mathrm{min}$. Vždy zavádíme intraaortální balonkovou kontrapulsaci (IABP), která je u nás dostupná jen v kardiocentrech s katetrizační laboratoří. IABP je jednoznačně indikována u pacientů s kardiogenním šokem nebo těžkým srdečním selháním po provedení prrímé PCI nebo před kardiochirurgickým výkonem (aortokoronární bypass, plastika nebo náhrada mitrální chlopně pro akutní mitrální insuficienci, uzávěr defektu komorového septa při jeho ruptuře, před transplantací srdce). U pacientů s nejtěžší formou s perspektivou srdeční transplantace lze s výhodou použít mechanických podpůrných srdečních systémů. ${ }^{(43,44)}$ Pacienta uměle ventilujeme. Přes maximální léčbu včetně přímé PTCA umírá na kardiogenní šok 40-50\% nemocných.

\subsection{Léčba infarktu myokardu pravé komory}

Infarkt myokardu pravé komory se nejčastěji vyskytuje společně s infarktem myokardu dolní stěny. Diagnózu stanovíme na základě klinického obrazu (hypotenze, zvýšená náplň krčních žil, nepřítomnost městnání na plicích), EKG záznamu ze svodů z pravého prekordia (elevace úseků ST ve V4R $>0,1 \mathrm{mV}$ ) a echokardiografie (dilatace pravé komory, segmentární porucha motility pravé komory, dilatace pravé síně). Základem léčby je kromě přímé PCI volumexpanze krystaloidy $\mathrm{v}$ dávce 1 000-2 $000 \mathrm{ml}$ během prvních hodin a $200 \mathrm{ml} / \mathrm{h}$ po oběhové stabilizaci. Pokud se při ní nezvyšuje krevní tlak, lze přidat infuzi s katecholaminy. Nevhodné jsou naopak vasodilatační látky (nitráty, inhibitory ACE, diuretika, opiáty), které hypotenzi ještě prohlubují. Okamžitě se snažíme vertovat případnou fibrilaci síní.

\subsection{Léčba mechanických komplikací akutního infarktu myokardu}

Výskyt mechanických komplikací se zavedením přímé PCI výrazně snížil. V současnosti je pozorujeme nejčastěji po technicky neúspěšné přímé PCI nebo u nemocných, u kterých PCI nebyla pro pozdní příchod provedena. Po úspěšné PCI se $s$ nimi setkáváme zcela výjimečně. Na mechanické komplikace infarktu myokardu myslíme vždy při náhlém zhoršení klinického stavu se známkami nízkého srdečního výdeje, plicního edému nebo kardiogenního šoku. Vyskytují se obvykle v prvním týdnu po akutním IM. Nejlepší diagnostickou metodou je echokardiografie. Při konzervativním způsobu léčby se úmrtnost pohybuje kolem 90 \%, při rychlém chirurgickém výkonu ji lze snížit přibližně na $50 \%$.

Ruptura volné srdeční stěny je u infarktu myokardu závažnou komplikací s velmi vysokou mortalitou. Většina nemocných umírá pod obrazem elektromechanické disociace dříve, než jim můžeme poskytnou kardiochirurgickou pomoc. Poměrně často se $s$ ní setkáváme u zemřelých $\mathrm{v}$ př̀ednemocniční fázi akutního IM. Přibližně u čtvrtiny pacientů se manifestuje jako subakutní nebo také skrytá ruptura. Diagnóza je klinicko-echokardiografická, kdy u nemocných se šokovým stavem a/nebo klinickým obrazem tamponády zjištujeme echokardiograficky tekutinu v perikardu, někdy s echodenzními masami. Pokud echokardiografie neumožní diagnózu, lze zvážit provedení magnetické rezonance. Kardiochirurgické řešení (zpravidla okamžité) je metodou volby.

Ruptura komorového septa vzniká u 1-2\% nemocných s infarktem myokardu. Projevuje se výrazným systolickým šelestem a zhoršením hemodynamického stavu nemocného. Diagnózu potvrdíme echokardiograficky, prrípadně katetrizačně. Metodou volby u hemodynamicky nestabilních pacientů je rychlé chirurgické řešení pomocí záplaty $\mathrm{v}$ místě defektu, doprovázené $\mathrm{v}$ indikovaných případech aortokoronárním bypassem, a to ihned po stanovení diagnózy. Okamžitě zavádíme balonkovou kontrapulsaci. Operaci je vhodné provést co nejdříve i u stabilizovaných nemocných s dobrou funkcí levé komory, protože vždy hrozí náhlé rozšíření defektu s hemodynamickým kolapsem. Výkon je ale často technicky velmi náročný s vysokým rizikem. V některých centrech jsou zkušenosti s perkutánním uzávěrem komorového defektu pomocí okluderu, výsledky nejsou přesvědčivě lepší než při chirurgickém řešení.

Akutní mitrální regurgitace. Většina případů mitrální regurgitace při akutním IM není závažná. U menšiny nemocných může akutně vzniklá těžká mitrální regurgitace $\mathrm{v}$ důsledku ischemie a následné ruptury papilárního svalu vést k těžkému plicnímu edému či ke kardiogennímu šoku a úmrtí. Mitrální poškození diagnostikujeme auskultačně, echokardiograficky, popř. katetrizačně. Ihned podáme i.v. nitráty s cílem snížit tlak v plicnici v zaklínění a zlepšit prokrvení periferie. Zavedeme IABK. Metodou léčby těžké mitrální regurgitace je brzký kardiochirurgický výkon s náhradou nebo výjimečně plastikou chlopně a revaskularizací. ${ }^{(45)}$ Odklad operace zhoršuje prognózu nemocných.

\subsection{Léčba arytmií v průběhu akutního infarktu myokardu}

Arytmie a poruchy rytmu jsou velmi časté během akutní fáze infarktu myokardu (prvních 48 hodin) a nemají vliv na dlouhodobou mortalitu. Vždy pátráme po prŕíčině arytmií (ischemie myokardu, hyperaktivace vagu a sympatiku, elektrolytové poruchy). Nebezpečné jsou především arytmie s hemodynamickými následky.

Komorové extrasystoly. Vyskytují se téměř u všech akutních IM. S výjimkou beta-blokátorů nepoužíváme jiná antiarytmika.

Komorová tachykardie. Krátké běhy komorové tachykardie jsou u akutního IM poměrně časté a nevyžadují speciální léčbu. Nebezpečné jsou setrvalé komorové tachykardie ( $\geq 30 \mathrm{~s}$ ), které mohou vést až $\mathrm{k}$ hemodynamickému zhroucení. Lékem volby je amiodaron. Při přetrvávání komorové tachykardie a jejím negativním dopadu na hemodynamiku je indikována elektrická kardioverze úvodní energií 200 J. Od komorové tachykardie (tepová frekvence [TF] > 120/min) musíme odlišit benigní akcelerovaný idio- 
ventrikulární rytmus ( $\mathrm{TF}<120 / \mathrm{min})$, který běžně vzniká při reperfuzi a spontánně odezní.

Fibrilace komor. Rozlišujeme primární a sekundární fibrilaci komor. Primární fibrilace komor se nejčastěji objevuje v prvních čtyřech hodinách akutního IM a poté její výskyt výrazně klesá. Nemocný, který přežije primární fibrilaci komor, má stejně dobrou dlouhodobou prognózu jako pacient bez ní. Naproti tomu k sekundární fibrilaci komor dochází až po 48 hodinách od vzniku IM, nejčastěji při těžkém srdečním selhání nebo kardiogenním šoku. Je známkou špatné prognózy a je indikací k implantaci kardioverteru-defibrilátoru. Fibrilaci komor léčíme okamžitou defibrilací nejlépe bifázickým výbojem o energii $200 \mathrm{~J}$ (při opakování výbojem 300 J a 360 J). Bifázický výboj méně poškozuje myokard a je stejně účinný jako doposud doporučované monofázické výboje. Základním lékem při resuscitaci je adrenalin, který podáváme $\mathrm{v}$ dávce 1-2 mg i.v. při asystolii, elektromechanické disociaci a po dvou neúspěšných defibrilačních výbojích u fibrilace komor. Dávku opakujeme po 3-5 minutách kardiopulmonální resuscitace. Vyšší dávky než $1 \mathrm{mg}$ při dalších bolusech (3-5 mg) můžeme zkusit po neúspěchu první dávky. Při komorové fibrilaci, nereagující na úvodní sérii defibrilací a adrenalin, podáme $300 \mathrm{mg}$ amiodaronu ve $20 \mathrm{ml}$ fyziologického roztoku rychlým bolusem. Opakovaná dávka je 150 mg i.v. Bikarbonát sodný lze podat až při dlouhotrvající resuscitaci (nejdříve po 10 minutách v dávce $1 \mathrm{mmol} / \mathrm{kg}$. Prospěšný je v prrípadě preexistující metabolické acidózy a př̀i hyperkalemii. ${ }^{(46)}$

Fibrilace síní. Fibrilace síní se vyskytuje asi u jedné pětiny infarktů, nejčastěji u velkých infarktů se srdečním selháváním. Nemocného ohrožuje především fibrilace síní s rychlou odpovědí komor, která zhoršuje jeho hemodynamický stav. $\mathrm{V}$ tomto př́padě můžeme podat amiodaron i.v. s cílem obnovit sinusový rytmus. Často postačuje zpomalení frekvence komor beta-blokátory nebo v případě systolického srdečního selhání digoxinem i.v. Při progresi ischemie nebo srdečního selhání v důsledku fibrilace síní indikujeme elektrickou synchronní kardioverzi. Recidivy jsou ale velmi časté. Nemocní s fibrilací síní musejí být účinně léčeni nefrakcionovaným nebo nízkomolekulárním heparinem a při jejím přetrvávání převedeni na perorální antikoagulancia.

Sinusová bradykardie. Sinusovou bradykardii zjištujeme u nemocných s AIM poměrně často (9-25\% případů). Nejčastěji se objevuje v první hodině akutního IM dolní stěny a při reperfuzi $\mathrm{v}$ povodí pravé věnčité tepny jako důsledek zvýšené aktivity parasympatiku (Bezoldův-Jarischův reflex). ${ }^{(47)}$ Je-li doprovázena hypotenzí, tak ji léčíme atropinem 0,5-3,0 mg i.v., př́padně dočasnou kardiostimulací.

Atrioventrikulární (A-V) blok. A-V blok I. a II. stupně Wenckebachova typu většinou nevyžaduje léčbu atropinem nebo kardiostimulací. A-V blok II. stupně Mobitzova typu a AV blok III. stupně jsou indikací $\mathrm{k}$ dočasné transvenózní kardiostimulaci, jestliže způsobují hypotenzi nebo srdeční selhání a nereagují na atropin (viz tabulka 12).
Tabulka 12 Indikace k dočasné transvenózní stimulaci při akutním infarktu myokardu

- Atrioventrikulární blokáda II. (Mobitz 2) nebo III. stupně s bradykardií způsobující hypotenzi nebo srdeční selhání a nereagující na atropin

- Sinusová bradykardie s hypotenzí nereagující na atropin

- Refrakterní komorové tachykardie při základním rytmu o frekvenci $<60 /$ min nebo při prodlouženém intervalu QTc

Asystolie. Vyžaduje okamžité zahájení kardiopulmonální resuscitace. Podáváme adrenalin $1 \mathrm{mg}$ i.v., další dávky můžeme opakovat po 3-5 minutách. Atropin aplikujeme intravenózně v dávce $1 \mathrm{mg}$ i.v., další dávky lze opakovat za 3-5 minut do celkové dávky 3,0 mg. Využíváme zprvu externí transkutánní, poté transvenózní dočasnou elektrickou kardiostimulaci. Význam transkutánní kardiostimulace se v souladu s technickým pokrokem zvyšuje. Její výhodou je neivazivnost výkonu a používá se především u pacientů s menším rizikem vzniku AV blokády jako profylaktické opatření. Transkutánní elektrická stimulace je méně účinná a pro nemocného nepř́ijemná. K dlouhodobější stimulaci používáme transvenózní dočasnou elektrickou stimulaci. Transvenózní elektrickou stimulaci lze také využít při „overdrivingu“ neustupujících komorových tachykardií.

\subsection{Poinfarktová angina pectoris}

Poinfarktová angina pectoris a prokázaná ischemie myokar$d u$ při zátěžovém vyšetření jsou indikací k časné koronarografii a podle nálezu na věnčitých tepnách $\mathrm{k}$ PCI nebo k aortokoronárnímu bypassu (CABG). Náhle vzniklé klidové stenokardie po PCI, které jsou ve většině př́padů doprovázené změnami na EKG, svědčí pro reokluzi věnčité tepny. Nejčastěji jde o subakutní trombózu ve stentu. Pacienta musíme okamžitě koronarografovat a provést rePCI.

\subsection{Léčba dalších komplikací}

Žilní trombóza a plicní embolie se při časné mobilizaci vyskytují zřídka. U nemocných, kteří vzhledem ke komplikacím vyžadují déletrvající klid na lůžku, aplikujeme nízkomolekulární heparin (LMWH) s.c. v profylaktické dávce dvakrát denně. Vzniklou žilní trombózu nebo plicní embolii léčíme plnou dávkou LMWH s.c. a následně 3-6 měsíců perorálními antikoagulanciemi. U masivní plicní embolie zvažujeme trombolýzu.

Nitrosrdeční tromby diagnostikujeme echokardiograficky nejčastěji u rozsáhlých infarktů přední stěny. Pohyblivé tromby léčíme nízkomolekulárním heparinem s.c. dvakrát denně v plné dávce a perorálními antiokoagulačními léky po dobu 3-6 měsíců. Před jejím ukončením musí být účinek léčby zkontrolován echokardiograficky.

Časná perikarditida (pericarditis epistenocardiaca) vzniká obvykle po 48 hodinách od začátku infarktu. Jedná se o suchou perikarditidu, projevující se horečkou, bolestmi na hrudi parietálního charakteru (spíše bodavé či píchavé, vázané na dýchání), perikardiálním třecím šelestem, zvý- 
šenou teplotou a často též supraventrikulárními arytmiemi. Obtíže se zhoršují při poloze na levém boku. Echokardiograficky obvykle nezjistíme žádný nebo minimální výpotek do $50 \mathrm{ml}$. Při zjištění tekutiny v perikardu vždy pomýšlíme na hemoperikard a omezujeme antitrombotickou léčbu. $\mathrm{V}$ případě obtěžujících bolestí na hrudi je vhodné krátkodobé podání kyseliny acetylsalicylové i.v. (1 000 mg/24 h) nebo nesteroidních protizánětlivých léků.

Pozdní perikarditida (Dresslerưv syndrom) nebo také „syndrom 3P“ (perikarditis, periarthritis humeroscapularis, pneumonitis) má spíše historický význam, dnes se téměř nevyskytuje. Podle starých učebnic začínala za několik týdnů po AIM a byla provázena zvýšenou teplotou. ${ }^{(48)}$ Doporučoval se paracetamol, analgetické dávky kyseliny acetylsalicylové, popř. kortikoidy.

\section{Sekundární prevence po propuštění z nemocnice}

\subsection{Ovlivnění kardiovaskulárních rizikových faktorů}

Kouření. Mortalita nemocných, kteří i po infarktu pokračují v kouření cigaret, je dvojnásobně vyšší než u těch, kteří kouřit přestali. Abstinence od kouření (ale i vyloučení pasivního kuřáctví) je nejúčinnějším opatřením v sekundární prevenci: žádný lék nedokáže snížit mortalitu o 50 \%, jak to dokáže přerušení kuřáckého zlozvyku! Každá nemocnice by měla mít určeného lékaře či zdravotní sestru odpovědnou za program odvykání kouření nemocných po infarktu myokardu a protokol odvykání kouření. Na kardiologických odděleních by měl platit samozřejmě zákaz kouření veškerého personálu.

Dieta - ovlivnění sérové koncentrace tuků. Všichni nemocní by měli mít dietu s omezením živočišných tuků a se zvýšeným podílem ovoce a zeleniny. Z celkového množství přijaté energie by tuky měly tvořit $30 \%, \mathrm{z}$ toho jednu třetinu by měly tvořit saturované mastné kyseliny („,cave trans mastné kyseliny“, které riziko zvyšují - smažená jídla, margaríny). Výsledná koncentrace LDL-cholesterolu je doporučována pod 2,5 mmol/l, u vysoce rizikových pacientů koncentrace LDL-cholesterolu $<2,0 \mathrm{mmol} / \mathrm{l}$ a celkového cholesterolu < 4,5 mmol/l. Výsledná koncentrace HDL-cholesterolu a triglyceridů není stanovena, avšak koncentrace HDL-cholesterolu $<1,0 \mathrm{mmol} / 1$ u mužů a $<1,2 \mathrm{mmol} / 1$ u žen a triglyceridů $>1,7 \mathrm{mmol} / 1$ se považují za ukazatele zvýšeného kardiovaskulárního rizika. ${ }^{(49)}$

Váhová redukce. Obézní nemocní by měli pomocí diety a fyzické aktivity zredukovat nadváhu. Cílem by měl být $\mathrm{BMI}<25 \mathrm{~kg} / \mathrm{m}^{2}$ a obvod pasu $<102 \mathrm{~cm} \mathrm{u}$ mužů a $<88 \mathrm{~cm}$ u žen.

Diabetes mellitus (DM). Epidemiologické studie prokázaly lineární závislost mezi koncentrací glykemie a rizikem kardiovaskulárního onemocnění. $\mathrm{Z}$ tohoto důvodu se doporučuje dlouhodobá a důsledná kompenzace diabetu (cílové hodnoty glykemie pro diabetes mellitus II. typu jsou: glykemie nalačno $<6,0 \mathrm{mmol} / 1$ nebo glykemie dvě hodiny po jídle $<7,5 \mathrm{mmol} / \mathrm{l}$ a koncentrace $\mathrm{HbA}_{1 \mathrm{C}} \leq 6,5 \%$ u obou typů diabetu. Dieta a redukce hmotnosti jsou základními opatřeními u diabetes mellitus 2. typu následované farmakologickou léčbou (p.o. antidiabetika, inzulin). Léky skupiny thiazolidindionů (glitazony) nejsou indikovány u pacientů po akutním IM. ${ }^{(50,51)} \mathrm{U}$ všech pacientů po infarktu myokardu bychom měli určit, zda mají normální metabolismus glukózy nebo poruchu glukózové tolerance či diabetes mellitus.

Hypertenze. Zvýšená koncentrace tlaku krve, a to jak systolického (TKs), tak diastolického (TKd), je kardiovaskulárním rizikem jak v primární, tak sekundární prevenci. Zvýšení TKs o 20 mm Hg a TKd o 10 mm Hg zvyšuje dvakrát riziko úmrtí na srdeční selhání a cévní mozkovou př́ihodu. Doporučované cílové hodnoty TK jsou < 140/90 mm Hg, u velmi rizikových pacientů a diabetiků $<130 / 80 \mathrm{~mm} \mathrm{Hg}$. Snížení krevního tlaku dosahujeme režimovými opatřeními (ty zahajujeme u všech pacientů s TK $<120 / 80$ mm Hg) nebo kombinací s léky (viz níže).

Koagulopatie, genetické odchylky. U pacientů s pozitivní rodinou anamnézou časného výskytu kardiovaskulární nemoci, familiární hyperlipidemií nebo koagulopatií a u nemocných s IM ve věku $<55$ let u mužů a $<65$ let u žen je vhodné pátrat po odchylkách $\mathrm{v}$ koagulačním systému (nejčastěji mutace genu pro faktor $\mathrm{V}$ a protrombin), metabolismu lipidů a prrípadně indikovat podrobné hematologické, biochemické či genetické vyšetření.

\subsection{Léky s protektivním účinkem na kardiovaskulární systém}

Antiagregancia/antikoagulancia. ASA 75-100 mg denně snižuje riziko reinfarktu nebo úmrtí až o $25 \%$, podáváme trvale. Clopidogrel v dávce $75 \mathrm{mg} /$ den přidaný k ASA nebo samotný při alergii na ASA je indikován po dobu jednoho roku u pacientů se STEMI bez ohledu na to, zda podstoupili nebo nepodstoupili reperfuzní léčbu.

Antikoagulancia p.o. jsou indikována: a) u STEMI indikovaných $\mathrm{k}$ p.o. antikoagulaci z jiného než koronárního důvodu (nemocní s aneurysmatem levé komory a nástěnnými tromby, nemocní s tromboembolickou nemocí, s permanentní fibrilací síní, s chlopenními protézami), kteří nemají implantován koronární stent; b) u stejné skupiny pacientů, kteří ale měli implantován stent (tj. indikovaným jak k warfarinu, tak i k ASA a clopidogrelu), je doporučována dávka ASA maximálně 70-100 mg, podávání clopidogrelu pouze po dobu jednoho měsíce po implantaci stentu a cílové INR při léčbě warfarinem 2,0-2,5. Kombinace warfarinu s ASA a clopidogrelem je spojena se zvýšeným rizikem krvácení. Podávání takové kombinace by mělo být na co možná nejkratší dobu (např. jeden měsíc po implantaci kovového stentu při kovové chlopenní protéze. $\mathrm{U}$ pacientů se stentem a jinou indikací $\mathrm{k}$ antikoagulaci a současně $\mathrm{s}$ krvácením $\mathrm{v}$ anamnéze lze podávat pouze clopidogrel a warfarin (bez ASA).

Hypolipidemika. Studie prokázaly př́znivý vliv na redukci koronárních příhod u pacientů s akutním koronárním syndromem, u kterých byla zahájena terapie během prvních čtyř dnů hospitalizace. Rovněž adherence $\mathrm{k}$ léčbě byla vyšší 
u těchto pacientů. Léčba statiny by měla být proto zahájena ještě během hospitalizace. Vyšetření koncentrace lipidů za tři měsíce od IM koriguje další léčbu. Léčba statinem snižuje mortalitu během pěti let o $30 \%$. Pro podávání fibrátů či jiných hypolipidemik jako léků první volby po akutním IM není dostatek důkazů.

Beta-blokátory. Redukce mortality a reinfarktu je srovnatelná s ASA, činí 20-25\%. Nasazení beta-blokátorů je indikováno u všech pacientů po STEMI bez ohledu na jejich kardiovaskulární riziko.

Blokátory renin-angiotensin-aldosteronového systému.

Inhibitory ACE. Jsou indikovány především u nemocných se STEMI s EF $\leq 40$ \% nebo s projevy srdečního selhání; dále u pacientů s hypertenzí, diabetem, chronickým renálním onemocněním. Je opodstatněné jejich podávání již od prvního dne, a mohou být podávány všem pacientům se STEMI, při respektování kontraindikací. Redukce mortality se projeví až po několikaletém sledování a snížení činí asi 20-25 \% (účinek kvantitativně podobný ASA a beta-blokátorům).

Blokátory receptorů $A T_{1}$ pro angiotensin II. Jsou indikovány u pacientů $s$ intolerancí inhibitorů ACE při dysfunkci LKS s EF $\leq 40$ \% nebo projevech srdečního selhání; nasazení i u ostatních pacientů po STEMI s intolerancí inhibitorů ACE se zdá prospěšné. Jejich kombinace $s$ inhibitory ACE je pravděpodobně prospěšná pouze u pacientů s pokročilejšími stadii srdečního selhání, kde stávající medikace je nedostatečná.

Antagonisté aldosteronových receptorů. Jsou indikovány u pacientů $\mathrm{s} \mathrm{EF} \leq 40 \%$ a známkami srdečního selhání nebo diabetes mellitus $\mathrm{k}$ již nasazeným inhibitorům ACE a beta-blokátorům (cave hyperkalemie).

Hormonální substituční terapie de novo estrogeny či kombinace s progesteronem není indikována jako sekundární prevence po proběhlém STEMI. ${ }^{(52)}$

Substituce vitaminy E, A či polyvitaminovými doplňky není indikována v rámci sekundární prevence ICHS. ${ }^{(52)}$

\section{Rehabilitace a životní styl po infarktu myokardu}

Detailní doporučení jsou obsažena $v$ doporučeních ČKS „Rehabilitace u nemocných s kardiovaskulárním onemocněním“"(53) Cílem rehabilitace je návrat nemocného do plnohodnotného života. Rehabilitace začíná několik hodin po přijetí do nemocnice a pokračuje $\mathrm{v}$ průběhu několika týdnů až měsíců po propuštění. Nemocného se zcela nekomplikovaným STEMI, s nemocí jedné tepny a léčeného úspěšnou primární PCI, lze propustit 3.-4. den. U nemocných s komplikacemi, s neúspěšnou primární PCI nebo se závažným koronarografickým nálezem na dalších tepnách postupujeme vždy prrísně individuálně. Hospitalizace u nich trvá 1-4 týdny (podle průběhu - nejdelší hospitalizaci vyžadují nemocní v akutní fázi resuscitovaní nebo několik dnů uměle ventilovaní). $\mathrm{V}$ následujících 3-4 týdnech po propuštění se nemocný pozvolna vrací k běžným domácím aktivitám. Po uplynutí 4-6 týdnů od infarktu absolvu- je nemocný závěrečné kardiologické vyšetření před nástupem do zaměstnání. ${ }^{(54)}$ Plné fyzické zátěže je schopen až ve druhém měsíci po infarktu. Rehabilitace po infarktu musí být bezpečná, pravidelná, na úrovni aerobní zátěže a musí obsahovat:

> pohybovou rehabilitaci a určení tréninkové zátěže,

> detailní informace o nutné změně životního stylu („protisklerotická" dieta, redukce váhy, abstinence kouření, dostatek pohybu),

> psychologickou pomoc a rady socio-ekonomické (návrat do zaměstnání).

Rehabilitace po propuštění z nemocnice může mít formu lázeňského pobytu (indikační skupina II/5, II/6 podle vyhlášky MZ 58/1997 Sb.), léčba trvá 28 dnů a je plně hrazena zdravotními pojištovnami; návrh předkládá kardiolog či internista. Jinou formou je řízený ambulantní či individuální trénink $\mathrm{v}$ rámci denních rehabilitačních skupin $\mathrm{v}$ místě bydliště (např. „Kluby kardiaků“ v rámci spolků či nadací, rehabilitační zařízení) ve spolupráci s ošetřujícím kardiologem.

\section{Literatura}

1. Thygesen K, Alpert JS, White HD; Joint ESC/ACCF/AHA/WHF Task Force for the Redefinition of Myocardial Infarction; Jaffe AS, Apple FS, Galvani M, Katus HA, Newby LK, Ravkilde J, Chaitman B, Clemmensen PM, Dellborg $\mathrm{M}$, Hod H, Porela P, Underwood R, Bax JJ, Beller GA, Bonow R, Van der Wall EE, Bassand JP, Wijns W, Ferguson TB, Steg PG, Uretsky BF, Williams DO, Armstrong PW, Antman EM, Fox KA, Hamm CW, Ohman EM, Simoons ML, Poole-Wilson PA, Gurfinkel EP, Lopez-Sendon JL, Pais P, Mendis S, Zhu JR, Wallentin LC, Fernández-Avilés F, Fox KM, Parkhomenko AN, Priori SG, Tendera M, Voipio-Pulkki LM, Vahanian A, Camm AJ, De Caterina R, Dean V, Dickstein K, Filippatos G, Funck-Brentano C, Hellemans I, Kristensen SD, McGregor K, Sechtem U, Silber S, Tendera M, Widimsky P, Zamorano JL, Morais J, Brener S, Harrington R, Morrow D, Lim M, Martinez-Rios MA, Steinhubl S, Levine GN, Gibler WB, Goff D, Tubaro M, Dudek D, Al-Attar N. Universal definition of myocardial infarction. Eur Heart J 2007;28: 2525-38.

2. Montalescot G, Dallongeville J, Van Belle E, et al. STEMI and NSTEMI: Are they so different? 1 year outcomes in acute myocardial infarction as defined by the ESC/ACC definition (the OPERA Registry. Eur Heart J 2007;28:1409-17.

3. Schiele F, Legalery P, Didier K, et al. Impact of renal dysfunction on 1-year mortality after acute myocardial infarction. Am Heart J 2006;151:661-7.

4. Fox KA, Steg PG, Eagle KA, et al. Decline in rates of death and heart failure in acute coronary syndromes, 1999-2006. JAMA 2007;297:1892-900.

5. Allen LA, O'Donnell ChJ, Camargo CA. Comparison of long-term mortality across the spectrum of acute coronary syndromes. Am Heart J 2006;151:1065-71.

6. Braunwald E. Acute myocardial infarction: the value of being prepared. N Engl J Med 1996;334:51-2.

7. Brieger D, Eagle KA, Goodman SC, et al. Acute coronary syndromes without chest pain, an underdiagnosed and undertreated high-risk group. CHEST 2004;126:461-9.

8. Widimský $P$, Janoušek $S$, Vojáček J. Doporučení pro diagnostiku a léčbu akutního infarktu myokardu. Cor Vasa 2002;44:K123-K143.

9. Van de Werf F, Bax J, Betriu A, Blomstrom-Lundqvist C, Crea F, Falk V, Filippatos G, Fox K, Huber K, Kastrati A, Rosengren A, Steg PG, Tubaro M, Verheugt $F$, Weidinger F, Weis M; ESC Committee for Practice Guidelines (CPG), Vahanian A, Camm J, De Caterina R, Dean V, Dickstein K, Filippatos G, Funck-Brentano C, Hellemans I, Kristensen SD, McGregor K, Sechtem U, Silber S, Tendera M, Widimsky P, Zamorano JL, Silber S, Aguirre FV, Al-Attar N, Alegria E, Andreotti F, Benzer W, Breithardt O, Danchin N, Di Mario C, Dudek D, Gulba D, Halvorsen S, Kaufmann P, Kornowski R, Lip GY, Rutten F. Management of acute myocardial infarction in patients presenting with persistent ST-segment elevation: the Task Force on the Management of ST-Segment Elevation Acute Myocardial Infarction of the European Society of Cardiology. Eur Heart J 2008;29:2909-45. 
10. European Resuscitation Council guidelines for resuscitation. Resuscitation 2005;67 (Suppl 1):S39-86.

11. COMMIT (Clopidogrel and Metoprolol in Myocardial Infarction Trial) collaborative group. Early intravenous then oral metoprolol in 45,852 patients with acute myocardial infarction: randomised placebo-controlled trial. Lancet 2005;366:1622-32.

12. Jerry $P$, Nolan A, Peter T, Morley B, et al. Therapeutic hypothermia after cardiac arrest. An advisory statement by the Advanced Life Support Task Force of The International Liaison Committee on Resuscitation. Resuscitation 2003;57:231-5.

13. Widimský $P$, Budesínský $T$, Vorác $D$, et al. Long distance transport for primary angioplasty vs immediate thrombolysis in acute myocardial infarction. Final results of the randomized national multicentre trial-PRAGUE-2. Eur Heart J 2003;24:94-104.

14. Andersen HR, Nielsen TT, Rasmussen $K$, Thuesen $L$, Kelbaek $H$, Thayssen $P$, Abildgaard U, Pedersen F, Madsen JK, Grande P, Villadsen AB, Krusell LR, Haghfelt T, Lomholt P, Husted SE, Vigholt E, Kjaergard HK, Mortensen LS DANAMI-2 Investigators. A comparison of coronary angioplasty with fibrinolytic therapy in acute myocardial infarction. N Engl J Med 2003;349:733-42.

15. Keeley EC, Boura JA, Grines CL. Primary angioplasty versus intravenous thrombolytic therapy for acute myocardial infarction: a quantitative review of 23 randomised trials. Lancet 2003;361(9351):13-20.

16. Svilaas T, Vlaar PJ, van der Horst I, et al. Thrombus aspiration during primary percutaneous coronary intervention. N Engl J Med 2008;358:557-67.

17. Widimský P, Groch L, Želízko M, et al. Multicentre randomized trial comparing transport to primary angioplasty vs immediate thrombolysis vs combined strategy for patients with acute myocardial infarction presenting to a community hospital without a catheterization laboratory. The PRAGUE study. Eur Heart J 2000;21:823-31.

18. Limi Vermeer F, Oude Ophuis A, Van den Berg E, et al. Prospective randomized comparison between thrombolysis rescue PTCA and primary PTCA in patients with extensive myocardial infarction admitted to a hospital without PTCA facilities: the LIMI study, a safety and feasibility study. Heart 1999;82:431-6.

19. ASSENT-4 PCI investigators. Primary versus tenecteplase-facilitated percutaneous coronary intervention in patients with ST-segment elevation acute myocardial infarction (ASSENT-4 PCI): randomised trial. Lancet 2006;367 (9510):569-78

20. Ellis SG, Tendera M, de Belder MA, van Boven AJ, Widimsky P, Janssens L, Andersen HR, Betriu A, Savonitto S, Adamus J, Peruga JZ, Kosmider M, Katz O, Neunteufl T, Jorgova J, Dorobantu M, Grinfeld L, Armstrong P, Brodie BR, Herrmann HC, Montalescot G, Neumann FJ, Effron MB, Barnathan ES, Topol EJ; FINESSE Investigators. Facilitated $\mathrm{PCl}$ in patients with ST-elevation myocardial infarction. N Engl J Med 2008;358:2205-17.

21. Freemantle $\mathrm{N}$, Cleland J, Young $P$, et al. Beta blockade after myocardial infarction: systemic review and meta regression analysis. Br Med J 1999; 318:1730-7.

22. Vaverková H, Soška V, Rosolová H, et al. Doporučení pro diagnostiku a léčbu dyslipidemií v dospělosti, vypracované výborem České společnosti pro aterosklerózu. Vnitř Lék 2007;53:181-97.

23. ISIS-4. A randomised factorial trial assessingearly oral captopril, oral mononitrate, and intravenous magnesium in 58,050 patients with suspected acute myocardial infarction. ISIS-4 (Fourth International Study of Infarct Survival) Collaborative Group. Lancet 1995;345:669-85.

24. Chinese Cardiac Study Collaborative Group. Oral captopril versus placebo among 13,634 patients with suspected myocardial infarction: interim report from the Chinese Cardiac study (CCS-1). Lancet 1995;345:686-7.

25. The Task Force on Diabetes and Cardiovascular Diseases of the European Society of Cardiology and of the European Association for the Study of Diabetes. Guidelines on diabetes, pre-diabetes, and cardiovascular diseases. Eur Heart J 2007;28:88-136.

26. Malmberg K, Ryden L, Wedel H, et al. Intense metabolic control by means of insulin in patients with diabetes mellitus and acute myocardial infarction (DIGAMI 2): effects on mortality and morbidity. Eur Heart J 2005;26:650-61.

27. Deedwania P, Kosiborod M, Barrett E, et al. Hyperglycemia and acute coronary syndrome. A Scientific Statement From the American Heart Association Diabetes Committee of the Council on Nutrition, Physical Activity, and Metabolism. Circulation 2008;117:1610-9.

28. Sarnak MJ, Levey AS, Schoolwerth AC, et al. Kidney disease as a risk factor for development of cardiovascular disease: a statement from the American Heart Association Councils on Kidney in Cardiovascular Disease, High Blood Pressure Research, Clinical Cardiology, and Epidemiology and Prevention. Hypertension 2003;42:1050-65.
29. Newby KH, Thomson T, Stebbins A, et al. Sustained ventricular arrhythmias in patients receiving thrombolytic therapy: incidence and outcomes. The GUSTO Investigators. Circulation 1998;98:2567-73.

30. Chockalingam A, Gnanavelu G, Subramaniam T, Dorairajan S, Chockalingam V. Right ventricular myocardial infarction: presentation and acute outcomes. Angiology 2005;56:371-6.

31. Hreybe H, Singla I, Razak E, et al. Predictors of Cardiac Arrest Occurring in the Context of Acute Myocardial Infarction. Pacing Clin Electrophysiol 2007;30:1262-6.

32. Camici PG, Prasad SK, Rimoldi OE. Stunning, hibernation, and assessment of myocardial viability. Circulation 2008;117:103-14.

33. Lalonde L, Ziadi MC, Beanlands R. Cardiac positron emission tomography: current clinical practice. Cardiol Clin 2009;2:237-55.

34. Kim RJ, Wu E, Rafael A, et al. The use of contrast-enhanced magnetic resonance imaging to identify reversible myocardial dysfunction. N Engl J Med 2000;343:1445-53.

35. Bytešník J. Doporučené postupy pro diagnostiku a léčbu komorových arytmií. Cor Vasa 2005;47 (Suppl):41-57.

36. Ezekowitz JA, Armstrong PW, McAlister FA. Implantable cardioverter defibrillators in primary and secondary prevention: a systematic review of randomized, controlled trials. Ann Intern Med 2003;138:445-52.

37. Táborský $M$, Kautzner J, Bytešník J, a spol. Doporučení pro implantace kardiostimulátorů, ICD a srdeční resynchronizační léčbu. Cor Vasa 2005;47 (Suppl):59-68.

38. http://www.kardio-cz.cz

39. Menon V, Pearte CA, Buller CE, et al. Lack of benefit from percutaneous intervention of persistently occluded infarct arteries after the acute phase of myocardial infarction is time independent: insights from Occluded Artery Trial. Eur Heart J 2009:30:183-9.

40. The Task Force for the diagnosis and treatment of acute and chronic heart failure 2008 of the European Society of Cardiology. Developed in collaboration with the Heart Failure Association of the ESC (HFA) and endorsed by the European Society of Intensive Care Medicine (ESICM). ESC Guidelines for the diagnosis and treatment of acute and chronic heart failure 2008. Eur Heart J 2008;29:2388-442.

41. Želízko M. Akutní infarkt myokardu s elevacemi ST úseku: Realita výsledky registru NRKI. XV. výroční sjezd České kardiologické společnosti. Brno, 14. 5. 2007.

42. Hochman JS, Sleeper LA, White HD, et al. One-year survival following early revascularization for cardiogenic shock. JAMA 2001;285:190-2.

43. Leshnower BG, Gleason TG, O'Hara ML, et al. Safety and efficacy of left ventricular assist device support in postmyocardial infarction cardiogenic shock. Ann Thorac Surg 2006;81:1365-70; discussion 1370-1.

44. Thiele H, Smalling RW, Schuler GC. Percutaneous left ventricular assist devices in acute myocardial infarction complicated by cardiogenic shock. Eur Heart J 2007;28:2057-63.

45. Chen Q, Darlymple-Hay MJ, Alexiou C, et al. Mitral valve surgery for acute papillary muscle rupture following myocardial infarction. Heart Valve Dis 2002;11:27-31.

46. European Resuscitation Council guidelines for resuscitation. Resuscitation 2005;67 (Suppl 1):S39-86.

47. Goldstein JA, Lee DT, Pica MC, et al. Patterns of coronary compromise leading to bradyarrhythmias and hypotension in inferior myocardial infarction. Coron Artery Dis 2005;16:265-74.

48. Studenčan M. Akutní koronární syndrom. Olomouc: Sport Media Group, 2007:123-4.

49. AHA/ACC Guidelines for Secondary Prevention for Patients With Coronary and Other Atherosclerotic Vascular Disease: 2006 Update. J Am Coll Cardiol 2006;47:2130-9.

50. Winkelmayer WC, Setoguchi S, Levin R, Solomon DH. Comparison of Cardiovascular Outcomes in Elderly Patients With Diabetes Who Initiated Rosiglitazone vs Pioglitazone Therapy. Arch Intern Med 2008;168:2368-75.

51. Guidelines on diabetes, pre-diabetes, and cardiovascular diseases: executive summary: The Task Force on Diabetes and Cardiovascular Diseases of the European Society of Cardiology (ESC) and of the European Association for the Study of Diabetes (EASD). Eur Heart J 2007;28:88-136.

52. AHA/ACC Guidelines for Secondary Prevention for Patients With Coronary and Other Atherosclerotic Vascular Disease: 2006 Update. J Am Coll Cardiol 2006;47:2130-9.

53. Chaloupka V, Siegelová J, Špinarová L, et al. Rehabilitace u nemocných s kardiovaskulárním onemocněním. Cor Vasa 2006;48:K127-K145.

54. Jirmář R, Nehyba S. Doporučení pro posudkovou činnost v kardiologii. Cor Vasa 1999;41:K178-K184. 